\title{
Maahanmuuttodiskurssit eduskuntapuolueiden vuoden 2015 vaalimateriaaleissa
}

\author{
IRINA HERNEAHO
}

\section{Johdanto}

Maahanmuutto on noussut keskeiseksi poliittiseksi kiistakysymykseksi koko Euroopassa viimeisen vuosikymmenen aikana. Suomen puoluekentällä teemaa on pitänyt esillä etenkin perussuomalaiset, joka on profiloitunut tiukan maahanmuuttopolitiikan kannattajana. Viimeistään perussuomalaisten kannatuksen nousu on pakottanut myös muut puolueet ottamaan kantaa maahanmuuttopoliittisiin kysymyksiin (Borg 2012: 1819; ks. myös Keskinen 2009). Keskustelu maahanmuutosta on vain kiihtynyt sen jälkeen, kun Suomeen saapui ennätyksellisen paljon turvapaikanhakijoita vuoden 2015 aikana. Todennäköisesti teeman painoarvo Suomen politiikassa tulevaisuudessa vain kasvaa.

Politiikassa on suurelta osin kyse kielestä (van Dijk 1997b: 18; Chilton 2004: 6). Politiikan diskurssi on olennainen vallankäytön paikka, jossa maahanmuuttopoliittiset linjaukset pyritään legitimoimaan. Tässä artikkelissa tarkastelen, millaisin kielellisin keinoin puolueet kuvaavat maahanmuuttoa vuoden 2015 eduskuntavaalien kampanjamateriaaleissaan. ${ }^{1}$ Muuttunut turvapaikanhakijatilanne ei ehtinyt nousta vielä kevään 2015 eduskuntavaaleissa merkittäväksi vaaliteemaksi, mutta maahanmuutto oli muutoin esillä puolueiden kampanjoinnissa. Vaikka maahanmuuton painoarvo politiikassa on kasvanut vuosi vuodelta, kielitieteellistä tutkimusta politiikan eliitin maahanmuuttolinjauksista ei ole Suomessa juuri tehty. Kansainvälisesti tutkimus on painottunut maahanmuuttovastaisiksi profiloituvien toimijoiden kielenkäyttöön (esim. Krzyżanowski 2013; Richardson \& Colombo 2014; Wodak 2014, 2015a). Tämän tutkimuksen tavoitteena on kaikkia puolueita tarkastelemalla tuoda esiin puolueiden välisiä yhtäläisyyksiä ja eroja sekä maahanmuuttopoliittisen keskustelun moninaisuutta.

Tutkimus pohjautuu kriittisen diskurssintutkimuksen viitekehykseen, jossa kielenkäyttöä tarkastellaan erityisesti vallankäytön ja yhteiskunnallisten seurausten näkö-

1. Artikkeli pohjautuu pro gradu -tutkielmaani (Herneaho 2016) ja on kirjoitettu Jenny ja Antti Wihurin rahaston myöntämällä apurahalla. Lämmin kiitos Anne Mäntyselle ja Jyrki Kalliokoskelle, jotka ovat lukeneet ja kommentoineet artikkelia prosessin eri vaiheissa. Kiitän myös kahta Virittäjän anonyymia arvioijaa arvokkaasta palautteesta, jota olen hyödyntänyt parhaani mukaan. 
kulmasta (esim. Fairclough 1992; van Dijk 1993; Pietikäinen 2000a; Blommaert 2005). Tästä näkökulmasta vaaliohjelmien maahanmuuttolinjaukset ovat olennainen tutkimuskohde, koska puolueilla on valtaan päästessään mahdollisuus muuttaa vaaliohjelmien linjauksia lainsäädännöksi (Railo 2013: 43). Poliittisen eliitin puhetavat voivat vaikuttaa myös siihen, miten maahanmuuttoon ja maahanmuuttajiin suhtaudutaan (van Dijk 1997a: 31-32). Kuten diskurssintutkimuksessa yleensä tavoitteenani on selvittää, millaisilla kielellisillä ilmauksilla merkityksiä rakennetaan eli miten maahanmuutosta puhutaan. Kriittisen perinteen mukaisesti mielenkiintoni kohdistuu myös siihen, miksi tekstit ovat sellaisia kuin ovat eli mitä niillä tavoitellaan. (Luukka 2000: 152-153.) Tutkimuskysymykseni ovat seuraavat: 1 . Millaisia maahanmuuttoon liittyviä diskursseja aineistosta on tulkittavissa? 2. Millaisin kielellisin keinoin diskursseja rakennetaan?

Artikkeli koostuu viidestä luvusta. Seuraavassa luvussa esittelen lyhyesti artikkelin kannalta relevanttia aiempaa tutkimusta sekä tutkimuksen teoreettisen viitekehyksen pääperiaatteet. Teoriaosuutta seuraa luku 3, jossa kerron tutkimusaineistosta ja analyysimenetelmistä. Luvussa 4 käsittelen aineistosta tunnistamiani neljää maahanmuuttodiskurssia. Päätösluvussa 5 kokoan tulokset, pohdin niiden merkitystä yhteiskunnallisessa kontekstissa ja esitän vaihtoehtoisia tulkintamahdollisuuksia; lisäksi ehdotan jatkotutkimusaiheita.

\section{Tausta}

Tässä luvussa luon ensin katsauksen maahanmuuttokeskustelua ja poliittisia ohjelmatekstejä käsittelevään tutkimukseen (alaluku 2.1). Alaluvussa 2.2 esittelen kriittisen diskurssintutkimuksen teoreettisia lähtökohtia ja avainkäsitteitä, jotka luovat perustan aineiston analyysille.

\subsection{Aiempi tutkimus}

Maahanmuuton representaatiot ja diskurssit ovat alusta asti lukeutuneet kriittisen diskurssintutkimuksen piirissä tutkituimpien teemojen joukkoon, mistä on kiittäminen erityisesti tutkimusperinteen tunnetuimpiin edustajiin kuuluvia Ruth Wodakia ja Teun A. van Dijkia. Wodak on tutkinut mittavasti rasistisia, antisemitistisiä ja diskriminoivia diskursseja (ks. esim. Wodak 1991, 1993, 2014, 2017; Reisigl \& Wodak 2001), ja van Dijkin tutkimukset ovat keskittyneet erityisesti siihen, miten yhteiskunnalliset eliitit uusintavat rasismia diskursiivisesti (ks. esim. 1992, 1997a, 2000, 2016). Wodakin ja van Dijkin (2000) yhdessä toimittama teos keskittyy parlamentaarisiin maahanmuuttodebatteihin Euroopassa.

Kriittisen diskurssintutkimuksen painopiste on viime vuosina usein ollut valtaansa kasvattaneiden maahanmuuttovastaisten, oikeistopopulististen ja äärioikeistolaisten liikkeiden kielenkäytössä ja diskursiivisissa strategioissa (ks. esim. Wodak, KhosraviNik \& Mral toim. 2013; Wodak \& Richardson toim. 2013; Richardson \& Colombo 2014; Wodak 2015a, 2017). Tästä perinteestä poiketen Blommaert ja Verschueren (1998) ovat tarkastelleet niin kutsuttua suvaitsevaisuusdiskurssia (discourse of tolerance), jonka 
voi näennäisestä maahanmuuttomyönteisyydestään huolimatta nähdä uusintavan maahanmuuttajien ja valtaväestön välistä eriarvoisuutta.

Suomalaisessa kielentutkimuksessa kriittisen diskurssintutkimuksen näkökulmia on hyödynnetty 1990-luvun puolivälistä lähtien. Kielen valtaa on kartoitettu muun muassa median ja politiikan diskurssin alueilla (ks. Kalliokoski 1995 toim.; Heikkinen 1999). Kriittisestä tutkimusperinteestä on ammentanut Pälli (2003) ihmisryhmien diskursiivista rakentumista analysoidessaan. Myös maahanmuuton ja etnisyyden esittämistä sanomalehdissä (Kuusisto 2000; Pietikäinen 200ob; Blomqvist 1992, 1995) sekä verkkokeskusteluissa (Lahti 2014) on tutkittu kriittistä lähestymistapaa soveltaen.

Yhteiskunnallista keskustelua maahanmuutosta on kartoitettu Suomessa laajasti myös muilla tieteenaloilla. Maahanmuuton, etnisyyden ja monikulttuurisuuden käsittelyä mediassa on tutkittu runsaasti (ks. esim. Raittila toim. 2002; Horsti 2005; Keskinen, Rastas \& Tuori toim. 2009; Haavisto 2011; Maasilta toim. 2012; Pöyhtäri 2014). Enenevässä määrin huomiota on viime vuosina kiinnitetty myös maahanmuuttoaiheiseen kansalaiskeskusteluun ja erityisesti sen maahanmuuttovastaisiin ääniin (ks. esim. Nikunen 2010; Haara 2012; Horsti \& Nikunen 2013). Maahanmuuton nousu valtakunnan politiikan keskiöön on innoittanut tutkimaan, millaisin argumentein, strategioin ja puhetavoin maahanmuuttopoliittisia kantoja oikeutetaan politiikassa. Lepolan (2000) väitöskirja keskittyy Suomessa 1990-luvulla käytyyn maahanmuuttopoliittiseen keskusteluun. Hatakka, Niemi ja Välimäki (2017) puolestaan käsittelevät artikkelissaan diskursiivisia strategioita, joita oikeistopopulistiset puolueet hyödyntävät vastatessaan mediassa rasismisyytöksiin.

Tämän tutkimuksen aineisto koostuu puolueiden eduskuntavaaleihin liittyvistä ohjelmateksteistä. Yhteiskuntatieteellistä puolueohjelmatutkimusta on tehty Suomessa runsaasti (ks. esim. Aarnio \& Kanerva toim. 1995; Aarnio \& Palonen toim. 1995; Aarnio 1998; Mickelsson 2002, 2004). Nimenomaan vaaliohjelmiin ovat keskittyneet muun muassa Niskanen (2011), Pyykkönen (2011) ja Railo (2013). Suomalaisessa kielentutkimuksessa poliittisia ohjelmatekstejä on tutkittu vielä vähän. Eduskuntavaaliohjelmien hyvinvointipuhetta ovat diskurssianalyysin ja korpuslingvistiikan keinoin kartoittaneet Karjalainen, Luodonpää-Manni ja Laippala (2017). Karlsson ja Wiberg (2010a, 2010b) tarkastelevat artikkeleissaan eduskuntapuolueiden ohjelmatekstien sanastoa ja kieliopillista kompleksisuutta; Kajaste (1995a, 1995b) on tutkinut poliittisten nuoriso- ja opiskelijajärjestöjen ohjelmien modaalisuutta ja argumentaatiota. Pro gradu -tutkielmissa on analysoitu myös vihreyden retoriikkaa kokoomuksen ympäristöpoliittisessa ohjelmassa (Pohjolainen 2012) sekä toimijaroolien rakentumista vihreiden periaateohjelmassa (Koistinen 2010). Tässä artikkelissa lähestyn vaaliohjelmia diskurssianalyyttisesti tavoitteenani tunnistaa erilaisia maahanmuuton merkityksellistämisen tapoja eli diskursseja (ks. Pietikäinen \& Mäntynen 2009: 19-21). Seuraavaksi esittelen lyhyesti artikkelini teoreettisia lähtökohtia.

\subsection{Kriittinen diskurssintutkimus maahanmuuttolinjausten kielen analyysissa}

Diskurssintutkimuksen keskiössä on käsitys kielenkäytöstä sosiaalisena toimintana. Yksiköllinen diskurssi viittaa samanaikaisesti sekä tutkimuksen teoreettiseen lähtökohtaan 
että tutkimuksen kohteeseen: kielenkäyttö ymmärretään sosiaaliseksi ja kontekstisidonnaiseksi toiminnaksi, mikä ohjaa tarkastelemaan, miten ja millä ehdoin merkitykset rakentuvat tilannekohtaisesti. (Luukka 2000: 138-141; Pietikäinen \& Mäntynen 2009: 12-14, 20-22.) Kielenkäyttö ei ole koskaan neutraalia tai näkökulmatonta vaan yhteydessä kielenkäyttäjän ja laajemman yhteisön arvostuksiin ja kielenkäytön konventioihin (Kalliokoski 1995a: 13-14). Myös kielikohtaiset ja yksilölliset merkityksenannon resurssit asettavat kielenkäytölle raamit: kielessä on oma keinovalikoimansa, josta kielenkäyttäjä tekee omien resurssiensa puitteissa kielellisiä valintoja kuhunkin kontekstiin ja omiin tavoitteisiinsa sopivalla tavalla (Johnstone 2008: 13-14; Pietikäinen \& Mäntynen 2009: 15).

Vaikka moninaiset normit ja konventiot säätelevät kielenkäyttöä, kielen avulla on mahdollista myös vastustaa ja muuttaa vanhoja järjestyksiä sekä luoda uusia tapoja jäsentää maailmaa. Kielen ja sosiaalisten käytänteiden suhde on toisin sanoen vastavuoroinen. Kielellä on siten voimaa muovata sosiaalista todellisuutta, mikä tekee kielenkäytöstä vallan näkökulmasta olennaisen kysymyksen. (Fairclough \& Wodak 1997: 258-259.) Kielen ja vallan välinen suhde sekä merkityksistä käytävä kamppailu ovat kriittisen diskurssintutkimuksen keskeinen mielenkiinnon kohde. Fairclough'n (1992: 238) mukaan diskurssi vaikuttaa siihen, mikä hyväksytään todeksi ja millaisiksi ihmisten sosiaaliset suhteet ja identiteetit muodostuvat. Kielenkäytön voi nähdä olemukseltaan poliittisena, sillä arkipäiväisissäkin keskusteluissa neuvotellaan siitä, mitä pidetään normaalina ja arvostettavana ja kuinka erilaisia "sosiaalisia hyödykkeitä", kuten valtaa, statusta ja rahaa, tulisi jakaa (Gee 2011: 5-7; vrt. Chilton 2004: 21).

Vaikka kriittisessä diskurssintutkimuksessa korostetaan kielen todellisuutta luovaa voimaa, tämä ei tarkoita, että todellisuus olisi redusoitavissa diskurssiin (ks. Fairclough 1992: 64-66; 2001b: 19-20). Kielenkäyttö on kuitenkin perustava osa lähes kaikkea sosiaalista toimintaa, ja siksi kielen analyysi avaa ikkunan yhteiskunnallisesti merkittäviin kysymyksiin. Kriittisessä tutkimusperinteessä kiinnostus kohdistuu erityisesti diskurssin rooliin epäsymmetristen ja dominoivien valtasuhteiden tuottamisessa ja ylläpitämisessä. Tutkimuksen painopiste on yleensä ollut yhteiskunnallisten eliittien ja instituutioiden harjoittamassa vallankäytössä ja diskriminaatiossa. (van Dijk 1993: 249-250; ks. myös Pietikäinen 2000a.) Tämän artikkelin lähestymistapa edustaa monessa mielessä perinteistä, tekstikeskeistä kriittistä diskurssintutkimusta: analyysin kohteena on yhteiskunnallisen, tarkemmin määriteltynä poliittisen eliitin kielenkäyttö (eduskuntapuolueiden vaaliohjelmat), jolla on seurauksia potentiaalisesti haavoittuvassa asemassa olevalle ihmisryhmälle (maahanmuuttajat ${ }^{2}$ tai tarkemmin rajatut maahanmuuttajataustaiset ihmisryhmät).

Analyysini kohdistuu siihen, millaisista näkökulmista maahanmuuttoa tarkastellaan ainestossani. Todellisuutta ja sen eri ilmiöitä, kuten maahanmuuttoa, on mahdollista jäsentää lukemattomilla tavoilla. Jotkin merkityksellistämisen tavat ovat ajan myötä kiteytyneet tunnistettaviksi ja taajaan käytetyiksi kielenkäytön resursseiksi. Tällaisista vakiintuneista, tietyistä näkökulmista asiaa tarkastelevista puhetavoista käytetään monikollista nimitystä diskurssit (ks. esim. Fairclough 1992: 3-4, 127-130;

2. On kuitenkin syytä huomioida, että maahanmuuttajien ryhmä on hyvin moninainen eikä kaikkien maahanmuuttajien asemaa ole aiheellista luonnehtia erityisen haavoittuvaksi. 
Johnstone 2008: 3), joka on tutkimukseni keskeinen käsite ja teoreettis-analyyttinen työkalu. Käsitteellä tarkoitetaan yhteiskunnallisista rakenteista ja järjestyksistä ammentavia merkityksellistämisen tapoja, jotka todentuvat kielessä suhteellisen vakiintuneella tavalla. Diskurssit ovat siis yhtä aikaa kielellisiä ja sosiaalisia ilmiöitä. (Pietikäinen \& Mäntynen 2009: 50-51.) Konkreettisten kielen yksiköiden sijaan diskurssit ovat abstraktioita, jotka todentuvat tekstissä ja puheessa (Solin 2002: 159-161). Käytän termiä tässä merkityksessä, kun erittelen aineistosta tulkitsemiani näkökulmia, joita ovat esimerkiksi talousdiskurssi (alaluku 4.1) ja ihmisoikeusdiskurssi (alaluku 4.2).

Diskurssit muodostuvat uskomusten, ajatusmallien ja ideologioiden pohjalta, ja ne paitsi ilmentävät myös muovaavat tapaa, jolla maailmaa tulkitaan (Johnstone 2008: 3). Tähän perustuu diskurssien valta: ne tuottavat, uusintavat, luonnollistavat ja muuttavat tapoja käsittää todellisuutta. Nämä tavat ovat yhteydessä valtasuhteisiin ja sosiaalisiin käytänteisiin. (Fairclough 1992: 67.) Erityisen vaikutusvaltaisina voidaan pitää sellaisia merkityksiä ja merkityksellistämisen tapoja, jotka ovat muodostuneet yleisesti hyväksytyiksi ja siten saavuttaneet hegemonisen aseman (ks. mts. 192-195). Hegemonialla tarkoitetaan valta-asemaa, joka perustuu pikemminkin suostutteluun ja liittolaissuhteisiin kuin suoraan voimankäyttöön (ks. Gramsci 1988; Blommaert 2005: 166-168). Hegemonian käsite auttaa ymmärtämään, miksi puolueet poliittisen kentän eri puolilta hyödyntävät samoja diskursseja ilman ulkoa tulevaa pakkoa. Heikkinen (1999: 71-72) nostaa kriittisen kielentutkimuksen keskeiseksi tehtäväksi nimenomaan luonnollistuneiden, itsestään selvinä pidettyjen merkitysten näkyväksi tekemisen. Merkityksistä kuitenkin käydään diskurssissa jatkuvaa kamppailua, ja hegemonisetkin merkitykset ja diskurssit voivat muuttaa muotoaan, menettää vaikutusvaltaansa ja painua marginaaliin (ks. Gee 2011: 38-39). Diskurssien vaikutusvalta on aina myös kontekstisidonnaista, ja niiden välinen hierarkia voi muodostua eri konteksteissa erilaiseksi (Pietikäinen \& Mäntynen 2009: 57-58).

On syytä huomata, että painottamalla tiettyä merkityksellistämisen tapaa rajataan samalla pois muita mahdollisia tarkastelukulmia (Pietikäinen \& Mäntynen 2009: 54). Fairclough'n (1992: 74-75) mukaan kielellisten valintojen taustalla vaikuttavat poliittiset motiivit. Tästä syystä maahanmuuttopoliittisessa keskustelussa saatetaan merkityksellistää sama ilmiö esimerkiksi turvapaikkashoppailuksi tai humanitaariseksi maahanmuutoksi: kielelliset valinnat tukevat omien tavoitteiden saavuttamista. Analyysini tavoitteena ei ole arvioida ja arvottaa erilaisia diskursseja esimerkiksi niiden "totuudellisuuden" perusteella vaan tarkastella niiden välisiä voimasuhteita ja analysoida, millaiset maahanmuuttoon liittyvät merkitykset ovat vaaliohjelmissa kiisteltyjä, marginaalisia, yleisiä tai kyseenalaistamattomia (Pietikäinen \& Mäntynen 2009: 11). Kriittisen perinteen mukaisesti tarkastelen aineistosta tulkitsemiani maahanmuuttodiskursseja erityisesti siitä näkökulmasta, miten niiden voi nähdä osallistuvan epäsymmetristen valtasuhteiden tuottamiseen, uusintamiseen ja haastamiseen.

\section{Aineisto ja menetelmät}

Tutkimusaineistoni koostuu puolueiden vuoden 2015 eduskuntavaaliohjelmien maahanmuuttoa käsittelevistä osista. Aineisto on julkaistu puolueiden verkkosivuilla marras- 
kuun 2014 ja maaliskuun 2015 välisenä aikana (ks. tarkemmin aineistolähteet). Edustettuina ovat kaikki kahdeksan eduskuntapuoluetta (suluissa puolueista käytetyt lyhenteet): Kansallinen Kokoomus (Kok.), Perussuomalaiset (PS), Suomen Keskusta (Kesk.), Suomen Kristillisdemokraatit (KD), Suomen ruotsalainen kansanpuolue (RKP), Suomen Sosialidemokraattinen Puolue (SDP), Vasemmistoliitto (Vas.) sekä Vihreä liitto (Vihr.). Puolueiden vaaliohjelmien maahanmuuttoa käsittelevien osioiden lisäksi aineistoon sisältyy perussuomalaisten maahanmuuttopoliittinen ohjelma, joka julkaistiin osana puolueen eduskuntavaalikampanjaa. ${ }^{3}$ Muilta puolueilta ei ilmestynyt vaalien alla vastaavaa, yksinomaan maahanmuuttoon keskittyvää poliittista ohjelmatekstiä. Tämä näkyy aineiston koostumuksessa siten, että perussuomalaisten tekstit muodostavat yli puolet koko aineiston laajuudesta, joka on 3436 sanetta. Vähiten aineistoa on keskustalta.

Puolueiden väliset erot aineiston määrässä kuvastavat osaltaan sitä, kuinka suuren painoarvon teema on kunkin puolueen vaalikampanjoinnissa saanut. Toisaalta on huomioitava, että puolueiden vaaliohjelmat eroavat toisistaan pituutensa ja muotonsa puolesta eivätkä tekstit tältä osin ole täysin vertailukelpoisia keskenään. Tästä huolimatta niiden voi katsoa edustavan samaa tekstilajia, ja puolueet ovat pääsääntöisesti itse nimenneet aineistoon sisällyttämäni tekstit vaaliohjelmiksi. Tekstilajin määrittelyssä Swales (1990: 45-47) nostaa ensisijaiseksi kriteeriksi yhteisen viestinnällisen päämäärän (communicative purpose). Vaaliohjelmien tapauksessa tekstien keskeinen tavoite on saada ihmiset äänestämään puoluetta. Vaaliohjelmat myös esittelevät puolueiden arvomaailmaa ja tavoiteltuja politiikkatoimia sekä houkuttelevat potentiaalisia äänestäjiä suhtautumaan niihin suopeasti (ks. Railo 2013: 41-43; vaaliohjelmien syntyprosessista ks. Karjalainen, Luodonpää-Manni \& Laippala 2017: 118-119). Viestinnällisen päämäärän ohella samaa tekstilajia edustavia tekstejä yhdistävät usein myös samankaltainen sisältö, rakenne, tyyli ja kohderyhmä (Swales 1990: 58; ks. myös Shore \& Mäntynen 2006). Tämän tutkimuksen tavoite ei kuitenkaan ole tuottaa tietoa vaaliohjelmista tekstilajina, vaan rajaus vaaliohjelmiin on lähinnä funktionaalinen: vaaliohjelmat ovat tarkoituksenmukainen tutkimusaineisto, kun tavoitteena on kartoittaa nimenomaan koko puolueen yhteisiksi hyväksyttyjä ja ajankohtaisia maahanmuuttolinjauksia. Analyysi ei kuitenkaan kerro tyhjentävästi puolueiden maahanmuuttopoliittisista kannoista vaan siitä, millaisin kielellisin keinoin maahanmuuttoa on merkityksellistetty vaalikampanjoinnissa.

Funktionaalisen kielikäsityksen mukaisesti analyysini lähtökohtana ovat merkitykset, eivät yksittäiset kielen piirteet tai rakenteet. Merkityksiä rakennetaan erilaisin leksikkokieliopillisin keinoin, mutta tulkintaan vaikuttavat myös kontekstuaaliset tekijät. (Luukka 2000: 139-141.) Mikrotasolla merkitykset rakentuvat tilanteisesti välittömässä tekstiyhteydessään, jossa kuitenkin on aina läsnä myös laajempi sosiokulttuurinen konteksti (kontekstin monikerroksisuudesta ks. Pietikäinen \& Mäntynen 2009: 29-37). Aineisto paikantuu tiettyyn aikaan ja paikkaan: vaaliohjelmat on tuotettu eduskuntavaaleja 2015

3. PS julkaisi vaalien alla lyhyen vaaliohjelman, jossa se esitteli eduskuntavaalien pääteemansa. Tämän lisäksi puolue julkaisi eri politiikan osa-alueita käsitteleviä poliittisia ohjelmia. Yksi tällainen on maahanmuuttopoliittinen ohjelma, jonka voi tulkita myös vaaliohjelman osaksi. Maahanmuuttopoliittisesta ohjelmasta, kuten myös muiden puolueiden vaaliohjelmista, olen rajannut aineiston ulkopuolelle kehitysyhteistyötä käsittelevät osat. Käytän PS:n lyhyestä vaaliohjelmasta lyhennettä Vo. ja maahanmuuttopoliittisesta ohjelmasta lyhennettä $\mathrm{Mp}$. 
varten, mikä näkyy aineistossa esimerkiksi viittauksina ajankohtaisiin yhteiskunnallisiin keskustelunaiheisiin. Tekstit ovat kuitenkin samanaikaisesti osa politiikan diskurssin historiallista jatkumoa, johon liittyvät esimerkiksi kunkin puolueen oma aatteellinen pohja ja tehdyt poliittiset päätökset. Oman kontekstinsa luovat myös aineiston puheenaiheena oleva ilmiö eli maahanmuutto sekä siihen eri yhteyksissä yhdistetyt puhetavat.

On tulkintakysymys, milloin puolueet käsittelevät mahanmuuttoa vaalimateriaaleissaan. Puolueet eivät pääsääntöisesti käsittele maahanmuuttoa rajatusti vain tietyssä osassa vaaliohjelmiaan, vaan maahanmuuttoaiheisiksi tulkittavia osioita voi olla eri puolella tekstiä. Yksiselitteisiä ovat tapaukset, joissa yhteys maahanmuuttoon eksplikoidaan esimerkiksi sananvalinnoilla, kuten pakolainen, siirtolainen tai maahanmuutto. Olen kuitenkin sisällyttänyt aineistoon myös tekstiä, jossa yhteys maahanmuuttoon ei ole yhtä ilmeinen. Olen esimerkiksi tulkinnut viittaukset rasismiin ja ihonväriin tai etniseen taustaan perustuvaan syrjintään maahanmuuttoaiheisiksi, vaikkei Suomi ole koskaan ollut etnisesti tai kulttuurisesti homogeeninen maa eikä esimerkiksi etnistä taustaa siten voi pitää eksplisiittisenä maahanmuuton merkitsijänä (ks. esim. Tervonen 2014). Tekstiyhteydessään nämä vaaliohjelmien ilmaukset ovat tulkittavissa nimenomaan maahanmuuttoon viittaaviksi. Diskurssijako ei kuitenkaan perustu yksinomaan sananvalintoihin, ja eri diskurssit voivat hyödyntää myös samaa sanastoa. Diskurssit ovat sanastollisia valintoja laajempi kielenkäytön ilmiö, ja tietty diskurssi voi aktivoitua, vaikkei mikään sananvalinta suoraan kytkeytyisikään tähän näkökulmaan. Diskurssit voivat erota toisistaan esimerkiksi metaforien, kategorisaation sekä toimijuuden kuvaamisen osalta (ks. Fairclough 2003: 129-133).

Aineiston rajaamisen jälkeen erittelin, millaisia erilaisia diskursseja aineistosta on tunnistettavissa. Diskurssien tunnistamisessa on kyse aktiivisesta tulkintaprosessista: diskurssit eivät odota tekstissä löytäjäänsä. Analyysivaiheessa arvioin ja luokittelin merkityksiä tukeutuen teoriaan sekä sosiokulttuuriseen ja kontekstuaaliseen tietoon siitä, miten maahanmuuttoa on mahdollista politiikan diskurssissa käsitellä. Lähestymistapani on hermeneuttinen: tutkittava kohde näyttäytyy esiymmärryksen valossa tietynlaisena, ja ymmärrys tutkimuskohteesta lisääntyy analyysin myötä, mikä avaa uusia näkökulmia aineistoon (Pietikäinen \& Mäntynen 2009: 143-144).

Seuraavassa luvussa esittelen ensin analyysin päätulokset, minkä jälkeen käyn alaluvuissa tarkemmin läpi aineistosta tunnistamiani diskursseja. Tässä artikkelissa ei ole mahdollista käsitellä kattavasti tutkimusaineistoa, mutta nostan kunkin diskurssin kohdalla esiin joitakin havainnollistavia aineistoesimerkkejä. Esimerkeistä tarkastelen lähemmin sellaisia kielellisiä valintoja, joihin kiteytyy jotakin olennaista tai kiinnostavaa koko diskurssin näkökulmasta. Analyysiluku kuitenkin pohjautuu koko tutkimusaineistosta tekemääni tekstuaaliseen analyysiin (ks. tarkemmin Herneaho 2016). ${ }^{4}$

4. Aineiston lausetason semanttisessa analyysissa olen hyödyntänyt systeemis-funktionaalisen kielentutkimuksen viitekehystä (esim. Halliday 1994; Shore 2012a, 2012b). Olen tarkastellut aineistoa kielen eri funktioiden näkökulmasta ja analysoinut tekstien kokemusmaailmaa (ideationaalinen metafunktio) ja asennoitumista (interpersonaalinen metafunktio) sekä sitä, miten tekstit rakentuvat ymmärrettäviksi kokonaisuuksiksi (tekstuaalinen metafunktio). Kielen analyysissa olen keskittynyt erityisesti prosesseihin, kategorisaatioon, modaalisuuteen, presuppositioihin ja implikaatioihin. Tässä artikkelissa en kuitenkaan käytä SF-teorian käsitteistöä. 


\section{Maahanmuuton neljä diskurssia}

Olen tunnistanut analyysin perusteella aineistosta neljä eri diskurssia, joita nimitän talous-, ihmisoikeus- ja turvallisuusdiskurssiksi sekä nationalistiseksi diskurssiksi. Jokaista diskurssia hyödyntää puolueista vähintään kaksi. Eri diskurssit representoivat maahanmuuttoa ja siihen liittyviä ilmiöitä, ihmisiä ja tapahtumia eri tavoin. Vaikka tekemäni analyysi on pääosin laadullista, taulukosta 1 käy ilmi diskurssien määrällinen jakauma. Taulukko antaa yleiskatsauksen siitä, kuinka laajasti ja mistä näkökulmista maahanmuuttoa on kunkin puolueen vaalimateriaalissa käsitelty.

Taulukko 1.

Puolueiden hyödyntämät diskurssit (luvut sanemääriä).

\begin{tabular}{|c|c|c|c|c|c|c|c|c|}
\hline $\begin{array}{l}\text { Puolue } \\
\text { ja koko } \\
\text { vaali- } \\
\text { ohjelman } \\
\text { laajuus }\end{array}$ & $\begin{array}{l}\text { KD } \\
(5167)\end{array}$ & $\begin{array}{l}\text { Kesk. } \\
\text { (1 934) }\end{array}$ & $\begin{array}{l}\text { Kok. } \\
\text { (3 294) }\end{array}$ & $\begin{array}{l}\text { PS } \\
\text { (2 272) }\end{array}$ & $\begin{array}{l}\text { RKP } \\
(4655)\end{array}$ & $\begin{array}{l}\text { SDP } \\
(2 \text { 184) }\end{array}$ & $\begin{array}{l}\text { Vas. } \\
\text { (5 227) }\end{array}$ & $\begin{array}{l}\text { Vihr. } \\
\text { (2 442) }\end{array}$ \\
\hline $\begin{array}{l}\text { Aineiston } \\
\text { laajuus } \\
(3436)\end{array}$ & 377 & 50 & 109 & 1898 & 480 & 156 & 310 & 56 \\
\hline $\begin{array}{l}\text { Talous- } \\
\text { diskurssi } \\
\text { (1 459) }\end{array}$ & X (164) & $X(50)$ & $X(76)$ & X (949) & X (159) & X (9) & X (17) & X (35) \\
\hline $\begin{array}{l}\text { Ihmis- } \\
\text { oikeus- } \\
\text { diskurssi } \\
\text { (912) }\end{array}$ & $X(80)$ & & & & X (339) & X (147) & X (310) & X (36) \\
\hline $\begin{array}{l}\text { Turval- } \\
\text { lisuus- } \\
\text { diskurssi } \\
\text { (954) }\end{array}$ & X (151) & & X (33) & X (770) & & & & \\
\hline $\begin{array}{l}\text { Nationa- } \\
\text { listinen } \\
\text { diskurssi } \\
\text { (969) }\end{array}$ & $X(26)$ & & & X (943) & & & & \\
\hline
\end{tabular}

Taulukon luvut kuvaavat sanemääriä. Puolueen nimeä seuraava luku kertoo koko vaaliohjelman laajuuden5: esimerkiksi kristillisdemokraattien vaaliohjelmassa on yhteensä 5167 sanetta. Perussuomalaisilla ilmoitettu vaaliohjelman laajuus, 2272 sanetta, muodostuu maahanmuuttopoliittisen ohjelman (1 958 sanetta) ja vaaliohjelman (314 sanetta) yhteenlasketusta sanemäärästä. Taulukon toiselta riviltä käy ilmi, kuinka paljon aineistoa eli maahanmuuttoa käsittelevää tekstiä kultakin puolueelta yhteensä on. Tutkimuksen koko aineiston laajuus (3 436 sanetta) saadaan laskemalla nämä luvut yhteen. Taulukon loput rivit kertovat aineistosta tunnistettujen diskurssien esiintymisestä. Rasti diskurssin kohdalla merkitsee, että puolue on hyödyntänyt kyseistä diskurssia

5. Luvut ovat suuntaa antavia. Sanemäärät on saatu syöttämällä vaaliohjelmien tekstimassa merkkilaskuriin. Sanemäärään ei sisälly kaavioihin, kuvatiedostoihin tai muihin vastaaviin upotettu teksti. 
vaalimateriaaleissaan. Rastia seuraava luku kuvaa sitä, kuinka paljon tiettyä diskurssia kunkin puolueen vaalimateriaaleissa on: esimerkiksi kokoomus on käsitellyt maahanmuuttoa talousnäkökulmasta 76 saneen verran.

Osa aineistosta on luokiteltu osaksi useampaa diskurssia, sillä eri diskurssit voivat olla läsnä ja lomittua lyhyenkin tekstikatkelman sisällä. Joskus yksikin sana voi aktivoida diskurssin (Fairclough 2003: 128; Pietikäinen \& Mäntynen 2009: 53). Tässä tutkimuksessa virke on pienin kielenkäytön yksikkö, jonka mukaan jako diskursseihin on tehty: jos samassa virkkeessä aktivoituvat vaikkapa talous- ja ihmisoikeusnäkökulma, koko virke on laskettu osaksi sekä talous- että ihmisoikeusdiskurssia. Esimerkiksi vasemmistoliitolla talousdiskurssin (17 sanetta) ja ihmisoikeusdiskurssin (310 sanetta) yhteenlaskettu laajuus (327 sanetta) on suurempi kuin puolueen koko aineiston laajuus (310 sanetta), koska vasemmistoliiton vaaliohjelman maahanmuuttoaiheinen osuus on kokonaisuudessaan luokiteltavissa osaksi ihmisoikeusdiskurssia, mutta osassa tekstiä maahanmuuttoa tarkastellaan myös talousnäkökulmasta.

Seuraavaksi (alaluvut 4.1-4.4) tarkastelen jokaista diskurssia erikseen. Aineistoesimerkit ovat alkuperäisessä kieliasussaan.

\subsection{Talousdiskurssi}

Talousdiskurssissa maahanmuuttoa tarkastellaan kansantaloudellisena kysymyksenä. Tällöin näkökulma on ennen kaikkea siinä, millaisia maahanmuuttajia Suomi tarvitsee. Talousdiskurssi on diskursseista ainoa, jota kaikki eduskuntapuolueet hyödyntävät vaalimateriaaleissaan, osa tosin vain marginaalisesti. Huomionarvoista on, että nekin puolueet, jotka ohjelmissaan painottavat voimakkaasti maahanmuuton ihmisoikeusnäkökulmaa (ks. alalukua 4.2), hyödyntävät teksteissään myös taloudellisia argumentteja. Talousdiskurssia voikin pitää aineistossa hegemonisena merkityksellistämisen tapana, jota puolueet eivät ole halunneet - tai voineet - ohjelmissaan sivuuttaa. Talousnäkökulma ei kampanjoinnissa rajoittunut vain maahanmuuttoon, sillä taloudesta muodostui kevään 2015 eduskuntavaalien pääteema. Erityisesti valtion velkaantuminen ja julkisen talouden tasapainottamisen tarve nousivat vaalikeskusteluissa toistuvasti esiin (Railo \& Ruohonen 2016). Kansantaloudellisen näkökulman korostuminen politiikassa ja myös muilla yhteiskunnan osa-alueilla on pitkäaikainen trendi. Fairclough (2001a: 127) puhuu kolonisaatiosta kuvatessaan taloudellisen kentän levittäytymistä kaikkia elämänalueita määrittäväksi elementiksi.

Talousdiskurssin sisältä erottuu kaksi katsantokantaa, jotka eroavat toisistaan siinä, esitetäänkö maahanmuutto talouden kannalta hyödyllisenä vai haitallisena ilmiönä. Eroista huolimatta niiden voi kuitenkin tulkita edustavan samaa diskurssia, koska molemmissa näkökulma on kansantaloudellinen. ${ }^{6}$ Tällainen puhetapa rakentaa kuvaa, jonka mukaan maahanmuuton oikeutus riippuu sen kansantaloudellisesta vaikutuksesta. Pakolaisia tai turvapaikanhakijoita ei pääsääntöisesti yhdistetä taloudelliseen hyötyyn.

6. Mielenkiintoinen, joskin tämän artikkelin näkökulman ja oman asiantuntemukseni ulottumattomissa oleva kysymys on, millainen suhde aineiston talousdiskurssilla ja ehdotetuilla talouspoliittisilla toimilla on taloustieteeseen. 
Niissä tapauksissa, joissa humanitaarista maahanmuuttoa käsitellään taloudellisessa viitekehyksessä, ilmiö merkityksellistetään lähes poikkeuksetta kansantaloutta uhkaavaksi tekijäksi. Kun maahanmuuton esitetään hyödyttävän Suomea taloudellisesti, puhe on lähes yksinomaan opiskelu- ja työperäisestä maahanmuutosta kuten esimerkeissä 1-3:

(1) EU:n ulkopuolelta saapuvien työntekijöiden työnteko-oikeutta koskevaa saatavuusharkintaa tulee väljentää maamme kilpailukyvyn vahvistamiseksi, yritysten työvoiman ja tarvittavien asiantuntijoiden saannin turvaamiseksi. (KD)

(2) Rakennetaan yhdessä kansainvälisten yritysten ja työvoimatoimistojen kanssa joustavampi käytäntö asiantuntijoiden työlupien vauhdittamiseksi Suomeen. (Kok.)

(3) Helpotetaan työperäistä maahanmuuttoa. Tarjotaan tänne opiskelemaan tulleille ulkomaalaisille riittävästi kielikoulutusta ja mahdollisuus pysyvään oleskelulupaan opintojen valmistumisen jälkeen.

(Vihr.)

Esimerkeissä 1-3 puheenaiheena ei ole maahanmuutto yleensä, vaan kyse on ennen kaikkea osaavista, yrityksiä ja kansantaloutta hyödyttävistä maahanmuuttajista. Kun maahanmuutto merkityksellistetään aineistossa taloutta hyödyttäväksi ilmiöksi, käytetään usein kursivoitujen kaltaisia substantiivilausekkeita. Esimerkissä 1 puhe on EU:n ulkopuolelta saapuvista työntekijöistä ja yritysten työvoimasta sekä vielä tarkemmin rajatusta ryhmästä eli tarvittavista asiantuntijoista. Myös esimerkissä 2 ehdotetaan toimenpiteitä nimenomaan asiantuntijoiden saamiseksi Suomeen. Esimerkissä 3 halutaan helpottaa ylipäätään työperäistä maahanmuuttoa sekä parantaa tietyiltä osin Suomessa opiskelevien ulkomaalaisten asemaa. Huomionarvoista on, että pysyvä oleskelulupa halutaan mahdollistaa vasta opintojen valmistumisen jälkeen. Ehdotus koskee näin maahanmuuttajia, jotka suorittavat tutkinnon loppuun.

Aineiston talousdiskurssissa opiskelu- ja työperäisen maahanmuuton kuvataan edistävän talouskasvua ja työpaikkojen syntymistä sekä tuovan tarvittavaa täydennystä työmarkkinoille. Joissakin tapauksissa työperäinen maahanmuutto esitetään erilaisilla modaalisilla kielenaineksilla jopa välttämättömänä: EU- ja ETA-maiden ulkopuolista työvoimaa koskevaa saatavuusharkintaa tulee väljentää (esim. 1) tai se on poistettava (Kesk.), koulutusvienti on saatava vauhtiin (Kesk.) ja työvoiman määrä on saatava kasvuun työperäisen maahanmuuton avulla (KD). Vaihtoehdottomuuden retoriikkaa hyödyntävät poliittisen eliitin edustajat myös muualla Euroopassa talouspoliittisia toimenpiteitä perustellessaan (esim. Fonseca \& Ferreira 2015; Borriello 2017). Modaalisten kielenainesten yleisyys talousdiskurssissa voi osin selittyä myös tekstilajiin liittyvillä konventioilla: erityisesti välttämättömyyttä ilmaisevat modaali-ilmaukset voivat olla tyypillisiä poliittisille ohjelmille ylipäänsä (Kajaste 1995a: 21).

Talousdiskurssille tyypillistä on myös talouden kuvaaminen tapahtumina ja tekoina, joissa ihminen on usein läsnä vain implisiittisesti. Karvosen (1995: 151-152, 155) 
mukaan talousteksteissä inhimillisten toimijoiden sijaan asioita saa usein aikaan jokin abstraktio. Inhimillisten toimijoiden häivyttämisen ohella tällaisilla kielellisillä valinnoilla myös yksinkertaistetaan monitahoisia taloudellisten prosessien kokonaisuuksia (Fairclough 2003: 138). Esimerkit 4 ja 5 havainnollistavat näitä ilmiötä aineiston talousdiskurssissa.

(4) Talouden uudistamisessa olemme valintatilanteessa. Me uskomme, että tätä maata voidaan uudistaa paremmaksi meille kaikille. - - Kansainvälisyys työmarkkinoilla luo lisää työpaikkoja.

(Vihr.)

(5) Työ ja opiskelu ovat kotouttamisen parhaat muodot. Diskriminointi etnisen taustan takia ei ole koskaan hyväksyttävää. Rasismia vastaan pitää käydä aktiivista taistelua. Haluamme suosia tasavertaista kohtelua ja yhteiskunnan monimuotoisuutta. Monimuotoisuus edesauttaa Suomen kasvua.

(RKP)

Tulkitsen esimerkkien 4 ja 5 viittaavaan maahanmuuttoon, vaikka käsitettä ei käytetäkään. Sen sijaan puhutaan kansainvälisyydestä ja monimuotoisuudesta, jotka luovat myönteistä kuvaa maahanmuutosta. On tosin huomattava, että mitenkään yksiselitteisesti esimerkeissä ei ole puhe vain maahanmuutosta: Kansainvälisyys työmarkkinoilla voi tarkoittaa paitsi maahanmuuttajien tulemista suomalaisille työmarkkinoille myös suomalaisten työntekijöiden kansainvälistymistä. Monimuotoisuuden voi ymmärtää maahanmuuttoa laajemmaksi ilmiöksi, mutta esimerkissä mainitut kotouttaminen, diskriminointi etnisen taustan takia ja rasismi aktivoivat tulkinnan, että kyse on ennen kaikkea maahanmuutosta. Esimerkkien 4 ja 5 maahanmuuttoa kuvaavista käsitteistä on luettavissa myönteinen asennoituminen väestön heterogeenisyyteen, mikä on aineistossa varsin epätyypillistä lukuun ottamatta ihmisoikeusdiskurssia (ks. alalukua 4.2).

Erilaisuutta ei kuitenkaan esitetä esimerkeissä itseisarvona vaan taloudellisen hyödyn lähteenä: maahanmuuton tarpeellisuutta perustellaan uusilla työpaikoilla ja talouskasvulla7. Maahanmuuton ja myönteisen taloudellisen kehityksen välille luodaan esimerkeissä kausaalinen suhde, jossa entiteetti (kansainvälisyys, monimuotoisuus) aikaansaa muutoksen toisessa entiteetissä (luo työpaikkoja, edesauttaa kasvua) (VISK \$463). Esimerkeissä ei ole epävarmuutta ilmaisevia modaalisia kielenaineksia ja syy-seuraussuhde esitetään kyseenalaistamattomana. Aineiston talousdiskurssille on muutoinkin tyypillistä kuvata talouden lainalaisuudet itsestään selvinä ja faktuaalisina - talouden ilmiöitä ei juuri selitetä, luokitella tai määritellä. Tällaisella puhetavalla on potentiaalisesti performatiivisia vaikutuksia: kuvaamalla talouden lainalaisuudet tietynlaisiksi samalla legitimoidaan ja toteutetaan kuvattuja toimintamalleja (Borriello 2017: 245).

Puolueista kristillisdemokraatit ja erityisesti perussuomalaiset rakentavat vaalimateriaaleissaan maahanmuutosta kuvaa myös taloudellisena uhkana. Siinä missä

7. Esimerkissä 5 ei tosin eksplikoida, että kyse on talouskasvusta. RKP kuitenkin käyttää myös muualla vaaliohjelmassaan käsitettä ilman talous-etuliitettä viittaamaan nimenomaan talouden kasvuun. 
hyödystä puhuttaessa maahanmuuttajat saavat aineistossa useimmiten opiskelijan tai työntekijän roolin, taloudellisen uhan kontekstissa maahanmuuttajat kuvataan sosiaaliturvan saajina - tai jopa sen hyväksikäyttäjinä. Tällöin puhe on useimmiten humanitaarisesta maahanmuutosta. Kielteinen asennoituminen käy ilmi jo siitä, millaisia nimityksiä perussuomalaiset käyttävät vaalimateriaaleissaan humanitaarisesta maahanmuutosta: turvapaikkashoppailu ja elintasosiirtolaisuus (PS: Mp.). Nimitykset rakentavat kuvaa, jonka mukaan maahanmuuttajat tulevat Suomeen ennen kaikkea paremman elintason perässä. Perussuomalaisten vaalimateriaaleissa esitetään, että maahanmuuttajat eivät työllisty tai edes halua tehdä töitä. Kristillisdemokraattien vaaliohjelmassa annetaan puolestaan ymmärtää, että myös työperäiseen maahanmuuttoon liittyy sosiaaliturvan väärinkäytöksiä.

Kun aineistossa rakennetaan maahanmuutosta kuvaa taloudellisena uhkana, esiin nousee kaksi teemaa: Ensinnäkin (humanitaarisen) maahanmuuton esitetään tulevan Suomelle kalliiksi, ja toiseksi maahanmuuttajien esitetään hyötyvän (taloudellisesti) järjestelmästä epäoikeudenmukaisella tavalla. Vaikka molemmissa tapauksissa maahanmuuttoa vastaan argumentoidaan taloudellisin perustein, jälkimmäisessä maahanmuutto hahmottuu ennen kaikkea moraaliseksi kysymykseksi. Etenkin perussuomalaisten maahanmuuttopoliittisessa ohjelmassa rakennetaan vastakkainasettelua suomalaisten veronmaksajien ja sosiaaliturvan varassa elävien maahanmuuttajien välille. Aineistossa veronmaksajilla viitataan nimenomaan suomalaisiin. Silloinkin, kun suomalaisuutta ei tekstissä eksplikoida, maahanmuuttajat ovat veronmaksajien implisiittinen vertailukohta. Tällaisen kategorisoinnin funktioksi voi tulkita moraalisen järjestyksen tuottamisen: diskurssissa tuotetaan kuvaa velvollisuuksista, joiden rikkominen on uhka yhteiskunnan moraaliselle järjestykselle (Jokinen, Juhila \& Suoninen 2012: 69-72). Esimerkissä 6 moraalista järjestystä rikkovat maahanmuuttajat, joiden esitetään käyttävän hyväksi turvapaikkajärjestelmää ja perheenyhdistämismenettelyä. Heidän vastapoolinaan esitetään työtä tekevä suomalainen eli tavallinen kansalainen, joka veroja maksamalla täyttää yhteiskunnalliset velvollisuutensa:

(6) Etenkin vaikeassa taloudellisessa tilanteessa veronmaksajien oikeustajua koettelee se, että maahanmuuton kustannusten annetaan jatkuvasti paisua. Turvapaikkajärjestelmän ja perheenyhdistämismenettelyn häikäilemätön käyttö elintasosiirtolaisuuden väylänä nakertaa kyseisten järjestelmien hyväksyttävyyttä tavallisen kansalaisen silmissä.

(PS: Mp.)

Esimerkissä 6 on puhe nimenomaan humanitaarisen maahanmuuton kustannuksista, mikä käy ilmi viittauksesta turvapaikkajärjestelmään. Tämän ja perheenyhdistämismenettelyn käyttö elintasosiirtolaisuuden väylänä esitetään esimerkissä kyseenalaistamattomana taustaoletuksena eli presuppositiona. Toimintaa kuvaillaan adjektiivilla häikäilemätön, mikä luo mielikuvan röyhkeistä, tietoisista ja laajamittaisista väärinkäytöksistä. Humanitaarisesta maahanmuutosta käytetty nimitys elintasosiirtolaisuus rakentaa kuvaa, jonka mukaan turvapaikanhakijoiden ja perheenyhdistämisen kautta saapuvien maahantulon ensisijainen motiivi on taloudellinen. Tämä taas nakertaa 
- - kyseisten järjestelmien hyväksyttävyyttä tavallisen kansalaisen silmissä. Kohosteisella verbivalinnalla (ks. KS s.v. nakertaa) humanitaarinen maahanmuutto merkityksellistetään yhteiskuntaa kalvavaksi ilmiöksi, joka rapauttaa luottamusta järjestelmiin eikä vastaa veronmaksajien oikeustajua. Veronmaksaja ja tavallinen kansalainen ovat kategorioita, joihin suuri osa tekstin potentiaalisista vastaanottajista voi samaistua, ja perussuomalaiset esittää ikään kuin näiden ryhmien nimissä, ettei maahanmuuttojärjestelmää pidetä hyväksyttävänä.

Aineistossa näkyy viitteitä Wodakin (2015a: 86) kuvaamasta tyypillisestä asennoitumisesta maahanmuuttoon: osaavat, vaurautta luovat maahanmuuttajat toivotetaan tervetulleiksi, mutta köyhät ja kouluttamattomat pyritään pitämään ulkopuolella. Aineiston perusteella rakentuu kuva koulutetusta ja osaavasta ihannemaahanmuuttajasta, joka vastaa yritysten tarpeita. Vähintään implisiittisesti muodostuu käsitys myös eitoivotuista maahanmuuttajista, jotka vaalimateriaalien perusteella ovat tulkittavissa köyhiksi, kouluttamattomiksi ja humanitaarisin syin maahan tulleiksi.

Taloudellisiin argumentteihin vedoten voidaan perustella niin työ- ja opiskeluperäisen maahanmuuton helpottamista kuin tuottamattomiksi arvioitujen maahanmuuttajien ulossulkemistakin. Merkille pantavaa on, että taloudellisella välttämättömyydellä perustellaan aineistossa sekä maahanmuuton helpottamista että sen rajoittamista. Laajemmin vaihtoehdottomuuden retoriikan voi nähdä epäpolitisoivan talouspolitiikkaa: puhetavan myötä talouspoliittiset toimenpiteet hahmottuvat ideologiasta irrallaan oleviksi kysymyksiksi, joiden perusteluksi riittää terve järki (Borriello 2017 244-245). Samalla tila puhua taloudellisten toimien ja uudistusten häviäjistä kapenee.

Talousdiskurssin voi nähdä legitimoivan tilannetta, jossa maahanmuuttajien asema on kytköksissä heidän tuottamaansa taloudelliseen hyötyyn, sillä odotus taloudellisesta hyödystä esitetään usein jo maahantulon ehdoksi. Maahanmuuttajat nähdään taloudellisena resurssina, jota hyödynnetään siltä osin kuin se palvelee kansantalouden etua. Tästä syystä diskurssi pikemminkin vahvistaa kuin haastaa hegemonista valtajärjestystä. Samalla on kuitenkin huomioitava, että taloudesta on mahdollista puhua monella eri tavalla ja myös aineiston talousdiskurssin sisällä esiintyy variaatiota esimerkiksi näkökulmissa ja ehdotetuissa toimenpiteissä. Eriävistä painotuksista huolimatta talousdiskurssi rajaa sitä, miten ja millä ehdoilla maahanmuutosta on mahdollista ja mielekästä puhua. Esimerkiksi maahanmuuttajille rakentuvat roolit typistyvät herkästi "talouden vetureihin" (työntekijät, opiskelijat) sekä "talouden taakkoihin" (sosiaaliturvan saajat). Huomionarvoista on, että vaaliohjelmista puuttuu näkökulma, jossa maahanmuuttajien (mahdollisesti) kohentunut taloudellinen asema nähtäisiin myönteisenä asiana.

Talousdiskurssin mahdolliset vaikutukset voivat olla moninaisia ja osin ristiriitaisiakin. Laajemmin talousdiskurssin vaikuttavuus liittyy talousnäkökulman korostuneeseen asemaan politiikassa ja yhteiskunnassa. Kamppailtaessa eriarvoisuutta vastaan talousnäkökulman hegemonia on ongelma, jos yhä useampi yhteiskunnallinen päämärä ymmärretään alisteiseksi taloudelliselle hyödylle. Kuitenkin juuri hegemoni-

8. Borriellon artikkeli käsittelee talouskuridiskurssia (austerity discourse), johon myös suuri osa tämän tutkimuksen talousdiskurssista on luettavissa. 
sen asemansa vuoksi talousdiskurssi voi olla tässä sosiokulttuurisessa kontekstissa toimiva keino legitimoida myös yhdenvertaisuutta ajavaa politiikkaa. Osa puolueista hyödyntääkin talousdiskurssia argumentoidessaan esimerkiksi syrjimättömyyden ja ihmisten yhdenvertaisen kohtelun puolesta (ks. esim. 5). Erityisen kiinnostavaa on, että talousdiskurssi näyttää olevan aineiston diskursseista ainoa, jonka avulla maahanmuutto merkityksellistetään toivottavaksi ilmiöksi. Vaikka ihmisoikeusdiskurssissa suhtautuminen maahanmuuttoon on lähtökohtaisen myönteinen, argumentaatio rakentuu (maahanmuuttajien) oikeuksien ja (Suomen) velvollisuuksien varaan. Seuraavaksi tarkastelen lähemmin aineiston ihmisoikeusdiskurssia.

\subsection{Ihmisoikeusdiskurssi}

Ihmisoikeusdiskurssissa näkökulma on Suomelle koituvan hyödyn tai haitan sijaan maahanmuuttajien oikeuksien toteutumisessa. Samalla Suomi representoidaan tahoksi, jolla on vastuu näiden oikeuksien toteutumisesta. Konkretian taso kuitenkin vaihtelee: Aineistossa on hyvin abstraktia ihmisoikeuspuhetta, jossa korostetaan kaikkien ihmisten yhtäläistä arvoa ja vastustetaan rasismia ja kaikkinaista syrjintää. Tämän lisäksi kiinnitetään huomiota tiettyjen ihmisryhmien marginaaliseen asemaan ja esitetään politiikkatoimenpiteitä tilanteen parantamiseksi. Charteris-Blackin (2014) jaotteluun ${ }^{9}$ pohjautuen abstraktin ihmisoikeuspuheen funktioksi voi tulkita yhteisten arvojen tuottamisen (consensus-building), kun taas politiikkatoimenpiteiden esittely tähtää poliittisten tavoitteiden legitimointiin (policy-making). Diskurssia hyödyntävät vaaliohjelmissaan kristillisdemokraatit, RKP, SDP, vasemmistoliitto ja vihreät, joista etenkin RKP ja vasemmistoliitto painottavat ihmisoikeusnäkökulmaa voimakkaasti.

Laajimmillaan ihmisoikeusdiskurssissa puhutaan ihmisryhmistä, joihin lukeutuvat kaikki (Suomessa elävät) ihmiset. Esimerkiksi nimitykset ihmiset, kaikki ja jokainen aktivoivat tulkinnan, ettei ryhmän ulkopuolelle rajata ketään. Tulkintaa vahvistaa se, että puolueet puhuvat usein samassa yhteydessä myös rasismista tai syrjinnästä. Näin laajoihin kategorioihin viitataan aineistossa erityisesti silloin, kun halutaan korostaa tiettyjen oikeuksien kuuluvan jokaiselle. Esimerkeissä 7 ja 8 on puhe ihmisarvon universaaliudesta:

(7) Me haluamme pitää kaikista suomalaisista huolta. Siksi tarvitaan reiluja uudistuksia, jotka takaavat - - ihmisarvoisen elämän lupauksen kaikille.

(Vihr.)

(8) On aika löytää keinot, joilla Suomi nousee pitkästä taantumasta maana, jossa ihmiset ovat yhdenvertaisia ja kaikkia kohdellaan oikeudenmukaisesti. Maana, jossa toteutuu kaikille kuuluva jakamaton ihmisarvo - - . (SDP)

9. Charteris-Blackin jaottelu koskee poliittisia puheita, mutta katson sen olevan tältä osin sovellettavissa myös kirjoitettuihin poliittisiin ohjelmiin. 
Esimerkin 7 ensimmäisessä virkkeessä konstruoidaan maahanmuuttajat potentiaalisesti ulossulkeva ryhmä [kaikki] suomalaiset. Kun seuraavassa virkkeessä perätään uudistuksia, jotka takaisivat ihmisarvoisen elämän lupauksen kaikille, rakentuu suomalaiset kuitenkin joustavaksi kategoriaksi, johon myös maahanmuuttajien on perusteltua tulkita kuuluvan. Suomalaisuuden rajoista on mahdollista neuvotella diskurssissa, koska kategorisaatiossa ei diskursiivisessa mielessä ole kyse ryhmien olemassaolosta tai ryhmään kuulumisen kielenulkoisista kriteereistä vaan erilaisista kielenkäytön resursseista, joilla ryhmiä rakennetaan (ks. Pälli 2003: 30-31).

Myös esimerkissä 8 on käytetty geneerisiä ihmistarkoitteisia nimityksiä (ihmiset ja universaali kvanttoripronomini kaikki), jotka yhdistettynä puheeseen yhdenvertaisuudesta ja kaikille kuuluvasta jakamattomasta ihmisarvosta rakentavat kuvaa siitä, ettei ryhmän ulkopuolelle rajata ketään. Ihmiset on esimerkki kategorisaatiosta, joka implikoi tiettyjä oikeuksia ja kutsuu suhtautumaan ihmisryhmään suopeasti (Kirkwood 2017; ks. myös Jokinen, Juhila \& Suoninen 2012: 52-53). Eksplisiittisten ihmisviittausten lisäksi ihmisoikeusdiskurssissa on myös epäsuoraa humanisaatiota (ks. esim. Kirkwood mts. 116-117), jossa tuodaan esiin maahanmuuttajien yksilöllisyyttä ja inhimillisiä ominaisuuksia.

Esimerkit 7 ja 8 havainnollistavat yhtä ihmisoikeusdiskurssin olennaista piirrettä: muista diskursseista poiketen ihmisoikeusdiskurssissa ei välttämättä tehdä eroa maahanmuuttajien ja valtaväestön välille. Kun puhe on ihmisoikeuksista, on kuitenkin perusteltua tulkita sanotun implisiittisesti koskevan myös maahanmuuttajia. Vaikka näkökulma ei tällöin rajoitu maahanmuuttoon, puhetavan voi katsoa osallistuvan maahanmuuttopoliittiseen keskusteluun tavalla, joka eroaa hyötynäkökulmasta (alaluku 4.1) ja haastaa ongelmakeskeiset lähestymistavat (ks. alalukuja 4.3 ja 4.4). Tällaisen puhetavan taustalla voi toki olla myös strateginen funktio: kun diskurssissa puhutaan laveasti kaikista, viesti voi olla useamman potentiaalisen äänestäjän hyväksyttävissä (ks. Kajaste 1995a: 201).

Ihmisoikeusdiskurssissa konstruoidaan lisäksi rajatumpia ryhmiä, joita yhdistää haavoittuva yhteiskunnallinen asema. Tällaisia ihmisryhmiä ovat aineistossa esimerkiksi (kiintiö)pakolaiset ja ihmiskaupan uhrit. Tarkempi kategorisointi on merkityksellinen kielellinen teko, koska se osoittaa, että puolueet ylipäätään tunnistavat marginalisoituja ihmisryhmiä. Tällainen kielenkäyttö voi olla vaikuttavampaa kuin abstrakti ihmisoikeuspuhe, josta on vaikeaa päätellä, kuinka sitoutuneita puolueet ovat edistämään marginalisoitujen ihmisten asiaa. Usein puolueet esittävät tarkemmin rajattujen ryhmien kohdalla myös konkreettisia toimenpiteitä niiden aseman parantamiseksi, kuten esimerkeissä 9 ja 10, joissa peräänkuulutetaan paperittomien eli passittomien oikeutta terveyspalveluihin ja koulutukseen:

(9) Paperittomien siirtolaisten on saatava terveydenhuoltoa ja oikeus äitiysneuvolapalveluihin. Paperittomille lapsille on kuuluttava samat oikeudet kuin muillakin, kuten oikeus perusopetukseen.

(Vas.)

(10) Haluamme antaa passittomille oikeuden terveydenhuoltoon ja koulutukseen. (RKP) 
Esimerkeissä 9 ja 10 esitellään lähes identtiset politiikkatoimenpide-ehdotukset, mutta ilmaisutavoissa on eroa: vasemmistoliiton vaaliohjelmasta poimitusta esimerkissä käytetään nesessiivistä on tehtävä -rakennetta (on saatava, on kuuluttava), minkä myötä toimenpiteet kuvataan välttämättöminä. RKP:n kantaa ilmentävässä esimerkissä sen sijaan on puhujan tahtoa ilmaiseva haluta-verbi (haluamme antaa), jonka käyttö toimenpide-ehdotusten yhteydessä näyttää olevan tunnusomaista nimenomaan RKP:n vaaliohjelmalle. Monikon ensimmäisen persoonan käytön eli "meinä" puhumisen voi tässä esimerkissä tulkita kielen keinoksi, jolla puolue rakentaa itsestään ja kenties myös kannattajistaan kuvaa humaanina ryhmänä, jota yhdistää halu parantaa paperittomien asemaa (ks. Pälli 2003: 95-98). Vaikka esimerkit ovat sisällöllisesti samankaltaisia, on syytä huomata ero koulutuksesta puhuttaessa: vasemmistoliitto vaatii oikeutta perusopetukseen paperittomille lapsille, joille puolueen mukaan kuuluvat samat oikeudet kuin muillakin. Vasemmistoliiton esimerkki implikoi, että vaatimus samoista oikeuksista ei koske paperittomia aikuisia. RKP sen sijaan ulottaa oikeuden koulutukseen geneerisesti passittomille.

Radikaaleimmillaan aineistossa ilmenee pyrkimys horjuttaa hegemonisia valtasuhteita, kuten käy ilmi esimerkistä 11. Esimerkissä on toisaalta abstraktille ihmisoikeuspuheelle tunnusomaisia piirteitä: siinä ei ehdoteta konkreettisia toimia tilanteen parantamiseksi, ja lisäksi siinä puhutaan ihmisoikeusdiskurssille tyypilliseen tapaan demokraattisesta ja oikeudenmukaisesta yhteiskunnasta, mikä ilman tarkempia määrittelyjä voisi tarkoittaa lähes mitä vain. Fairclough'n (2001b: 19) mukaan keskeiset kiistat politiikassa koskevatkin sitä, millaisia merkityksiä demokratian tapaisille käsitteille annetaan. Esimerkissä 11 määritellään demokraattisen ja oikeudenmukaisen yhteiskunnan tarkoittavan kaikkien yhtäläistä ja yhdenvertaista osallistumismahdollisuutta kaikilla yhteiskunnan osa-alueilla, minkä voi nähdä diskursiivisena kamppailuna hierarkkista valtajärjestystä vastaan.

(11) Demokraattinen ja oikeudenmukainen yhteiskunta edellyttävät kaikkien yhtäläistä ja yhdenvertaista osallistumismahdollisuutta kaikilla yhteiskunnan osaalueilla. Varallisuus, etninen tausta, sukupuoli tai seksuaalisuus eivät saa rajoittaa ihmisten mahdollisuutta osallistumiseen. Poliittisen ja taloudellisen vallan kasautuminen harvoille ei ole enemmistön tai yhteiskunnan etu.

(Vas.)

Esimerkki 11 on mielenkiintoinen erityisesti kategorisaation näkökulmasta. Ihmisiin viitataan geneerisillä nimityksillä kaikki ja ihmiset, joiden voi tulkita tarkoittavan kaikkia suomalaisen yhteiskunnan jäseniä. Inklusiivisuutta lisää se, että tekstissä on eksplikoitu seikkoja, jotka esimerkin mukaan eivät saa rajoittaa ihmisten mahdollisuutta osallistumiseen. Luetelluista ominaisuuksista etnisen taustan voi tulkita viittaavan erityisesti maahanmuuttajataustaisiin ihmisiin. Tämän lisäksi esimerkissä puhutaan myös enemmistön ja yhteiskunnan edusta, mitä esimerkin mukaan ei edusta poliittisen ja taloudellisen vallan kasautuminen harvoille. Kategorisointi enemmistöön ja tämän vastapooliin eli harvoihin tehdään valta-aseman perusteella: enemmistöllä ei ole merkittävästi poliittista ja taloudellista valtaa, harvoilla eli vähemmistöllä sen sijaan on. Maahanmuuttajista 
on tavallista puhua vähemmistönä, mutta tässä esimerkissä maahanmuuttajat tai etniseltä taustaltaan "ei-suomalaiset" yhteiskunnan jäsenet rakentuvat implisiittisesti osaksi enemmistöä sikäli, kun he eivät edusta poliittista tai taloudellista valtaeliittiä.

Esimerkki 11 havainnollistaa, kuinka ryhmät rakentuvat diskursiivisesti (ks. Pälli 2003: 35-36). Yhteiskunnallisessa maahanmuuttokeskustelussa ja myös tämän tutkimuksen aineistossa on tyypillistä kategorisoida ihmisiä syntyperäisiin suomalaisiin ja maahanmuuttajiin. Tämä on kuitenkin vain yksi mahdollisuus, ja erilaiset poliittiset motiivit ohjaavat tekemään erilaisia kielellisiä valintoja (Fairclough 1992: 74-75). Esimerkissä 11 ihmisiä luokitellaan syntyperän sijaan valta-aseman perusteella, jolloin maahanmuuttokeskustelulle tyypillisiä raja-aitoja "meidän" ja "heidän" välille ei rakennu. Ryhmiä konstruoidaan tavalla, joka haastaa vakiintuneiden ryhmärajojen ohella myös niihin liittyviä hegemonisia valtasuhteita. Huomattavaa kuitenkin on, että esimerkin voima perustuu vastakkainasetteluun eri ihmisryhmien välillä - nyt ryhmärajat vain rakentuvat toisin, "valtaeliitin" ja "vallattomien" välille.

Ihmisoikeusdiskurssia voi pitää aineiston ainoana diskurssina, joka haastaa maahanmuuttoon liittyviä epäsymmetrisiä valtasuhteita. Tässä suhteessa ihmisoikeusdiskurssin merkitystä ei voi väheksyä, mutta sen vaikuttavuuden voi myös kyseenalaistaa. Ensinnäkin abstrakti ihmisoikeuspuhe ei sido puolueita konkreettisten toimenpiteiden toteuttamiseen; tasa-arvon ja oikeudenmukaisuuden tapaiset käsitteet on mahdollista määritellä aina uudelleen kulloiseenkin tilanteeseen sopivalla tavalla (ks. Blommaert 2005: 193-194). Toiseksi ihmisoikeusdiskurssissa esitettyjen konkreettisten politiikkatoimenpiteiden osalta voi kysyä, vaikuttaisivatko ne toteutuessaankaan merkittävällä tavalla valtasuhteisiin: esimerkiksi terveydenhuolto-oikeuden takaaminen olisi toki konkreettinen parannus paperittomien ihmisten asemaan, mutta se ei silti tekisi heistä yhdenvertaisia suhteessa valtaväestöön. Ihmisoikeusdiskurssissa pyritään pääasiassa korjaamaan olemassa olevan järjestelmän epäkohtia puuttumatta niiden fundamentaaliseen perustaan (ks. mts. 167-168).

Kolmas ihmisoikeusdiskurssin vaikuttavuuteen liittyvä kysymys koskee sen legitimiteettiä, joka on sitten eduskuntavaalien 2015 asetettu monin paikoin kyseenalaiseksi. Vaikka vaaleissa suurin osa puolueista hyödynsi ihmisoikeusdiskurssia maahanmuuttoa käsitellessään ja vaikka ihmisoikeuksien korostamisella on ollut suuri - vähintään retorinen (Blommaert \& Verschueren 1998: 107) - rooli eurooppalaisessa poliittisessa kulttuurissa, ihmisoikeuksien painoarvo saattaa politiikassa olla vähenemässä (esim. Hopgood 2013). Ihmisoikeuksista ja kansainvälisistä sopimuksista on ainakin puheen tasolla irtisanouduttu poliittisen eliitin kannanotoissa niin Suomessa, muualla Euroopassa kuin Yhdysvalloissakin (ks. Amnesty 2017). Irtiottoja on usein perusteltu maahanmuuton aiheuttamalla turvallisuusuhalla. Myös tämän tutkimuksen aineistossa maahanmuutosta luodaan kuvaa turvallisuusuhkana, ja käsittelen seuraavaksi lähemmin tätä tematiikkaa.

\subsection{Turvallisuusdiskurssi}

Puolueista perussuomalaiset, kristillisdemokraatit ja marginaalisesti myös kokoomus käsittelevät vaalimateriaaleissaan maahanmuuttoa turvallisuuskysymyksenä. Turvallisuus- 
diskurssissa maahanmuutto yhdistetään konkreettisiin turvallisuusuhkiin, kuten yhteiskunnalliseen rauhattomuuteen, rikollisuuteen ja terrorismiin. Diskurssissa luodaan uhkaavaa kuvaa humanitaarisesta maahanmuutosta ja erityisesti tietyistä maahanmuuttajataustaisista ryhmistä, joita yhdistää ei-länsimaisuus. Puolueista perussuomalaiset eksplikoi yhteyden maahanmuuton ja turvallisuusuhkien välillä ja luo samalla hyvin kielteistä kuvaa maahanmuuttajista (ks. esim. 12). Maahanmuuton kuvataan horjuttavan turvallisuutta Suomessa ja koko Euroopassa:

(12) Maahanmuutto - - johtaa asuinalueiden gettoutumiseen, edistää uskonnollista radikalismia ja sen lieveilmiöitä sekä ruokkii etnisiä konflikteja. Esimerkkeinä näistä ilmiöistä voidaan mainita useita Euroopan suurkaupunkeja viime vuosina riivanneet etniset mellakat ja lähinnä maahanmuuttajanuorista koostuneet väkivaltaiset jengit.

(PS: Mp.)

Esimerkin 12 ensimmäisen virkkeen verbit johtaa, edistää ja ruokkii ovat semanttisesti kausatiivisia. Maahanmuuton ja turvallisuusuhkien välille luodaan kausaalinen yhteys: maahanmuutto kuvataan esimerkissä toimijana, joka aikaansaa muutoksen toiminnan kohteissa (VISK \$463). Maahanmuuton ja esimerkissä kuvattujen kielteisten ilmiöiden eli gettoutumisen, uskonnollisen radikalismin ja etnisten konfliktien välillä esitetään olevan väistämätön suhde. Konstruktiota perustellaan väitteillä useita Euroopan suurkaupunkeja riivaavista etnisistä mellakoista sekä väkivaltaisista jengeistä, jotka esimerkin mukaan koostuvat lähinnä maahanmuuttajanuorista. Esimerkin toisessa virkkeessä on useita kielenaineksia, joiden avulla maahanmuuttajista rakennetaan uhkaavaa kuvaa. Mellakka-käsitteeseen sisältyy implisiittisesti epätoivottu toiminta, joka on omiaan herättämään turvattomuuden tunnetta. Tätä vahvistaa myös käsitettä määrittävä, sävyltään hyvin kielteisen riivata-verbin NUT-partisiippimuoto riivanneet. Kategorisoiva adjektiivimäärite etninen implikoi, että erilaiset etniset taustat ovat mellakoiden selittävä tekijä tai syy. Sama implikaatio sisältyy myös esimerkin 12 ensimmäisen virkkeen ilmaukseen etnisiä konflikteja. Toiminnallisuutta esimerkissä rakentaa myös lähinnä maahanmuuttajanuorista koostuneiden jengien kuvaaminen väkivaltaisiksi.

Ei-toivotun toiminnan esittäminen ryhmän ominaisuutena voi rakentaa kielteistä kuvaa koko ihmisryhmästä (Pälli 2003: 124). Turvallisuusdiskurssissa uhkaavan toiminnan voi katsoa rakentuvan maahanmuuttajien ryhmäominaisuudeksi, minkä myötä maahanmuutto näyttäytyy kimppuna ongelmia. Usein turvallisuusuhat yhdistetään aineistossa johonkin tarkemmin rajattuun ihmisryhmään. Tällaisia maahanmuuttajatarkoitteisia nimityksiä ovat perussuomalaisilla (Romaniasta ja Bulgariasta kotoisin olevat) romanit, somalit sekä paperittomat, joista käytetään myös nimitystä maassa laittomasti oleskelevat. Kaksoiskansalaisuuden yhteydessä puhutaan strategisesta turvallisuusriskistä. Kristillisdemokraatit nostaa turvallisuusdiskurssissa esiin pakolaiset esittäessään, että pakolaiskiintiön kohdentamisessa on otettava huomioon sisäisen turvallisuuden näkökulmat. Kun tarkastellaan aineistossa nimettyjä maahanmuuttajaryhmiä, kenties kaikkein jyrkin kielenkäyttö liittyy ulkomaalaistaustaisiin romaneihin, joihin perussuomalaiset yhdistää erilaisia enemmän tai vähemmän järjestäytyneen rikollisuuden muotoja: 
(13) Paperittomien palvelut ja kerjäläisongelma

Suomen, kuten muidenkin Länsi-Euroopan maiden, kaupunkeja ovat Romanian ja Bulgarian EU-jäsenyyden alkamisesta lähtien riivanneet näistä maista saapuneet romanikerjäläiset. Kerjäläisyyteen liittyy runsaasti enemmän tai vähemmän järjestäytynyttä rikollisuutta kuten katuryöstöjä, myymälävarkauksia sekä asuntomurtoja. Näihin ilmiöihin voidaan puuttua tehokkaimmin kieltämällä kerjääminen järjestyslaissa.

(PS: Mp.)

Esimerkin 13 ensimmäisessä virkkeessä aktiivisen toimijan roolissa ovat Romaniasta ja Bulgariasta saapuneet romanikerjäläiset, joiden kuvataan riivanneen Suomen, kuten muidenkin Länsi-Euroopan maiden, kaupunkeja. Kielitoimiston sanakirjan (KS s.v. riivata) mukaan verbiä riivata käytetään "paholaisesta, pahoista voimista, taudeista tms.", ja ihmisryhmästä puhuttaessa vaikutelma on dehumanisoiva. Verbivalinnan myötä Romanian ja Bulgarian romanit merkityksellistetään ikään kuin yhteiskuntaa vaivaavaksi sairaudeksi tai voimaksi. Tämä yhdistettynä esimerkin otsikon kerjäläisongelmasubstantiiviin luo romaneista voimakkaan kielteistä kuvaa. Läheskään aina ihmisryhmiä ei aineistossa merkityksellistetä turvallisuusuhaksi näin suoraan. Romaneista voi Euroopan kenties syrjityimpänä ihmisryhmänä (esim. Amnesty 2014) olla hyväksytympää puhua avoimen diskriminoivasti kuin muista ryhmistä. Huomionarvoista on myös se, että esimerkissä 13 tilanteen ratkaisuksi tarjotaan kerjäämisen kriminalisoimista, jolloin tavoitteena ei ole parantaa haavoittuvassa asemassa olevan ihmisryhmän asemaa tai ennaltaehkäistä sosiaalisia ongelmia vaan saada romanit pois katukuvasta. Eksplikoimatta jää, miten kerjäämisen kieltäminen ehkäisisi katuryöstöjä, myymälävarkauksia ja asuntomurtoja. Esimerkissä 13 on myös epäsuoraa kritiikkiä Euroopan unionia kohtaan, kun kerjäläisyyteen yhdistettyjen ongelmien esitetään saaneen alkunsa EU-jäsenyyden alkamisesta.

Edellä mainittujen ihmisryhmien lisäksi aineistossa on puhe myös islaminuskoisista ihmisistä, joita tulkintani mukaan kaikki turvallisuusdiskurssia hyödyntävät puolueet käsittelevät teksteissään. Merkille pantavaa kuitenkin on, ettei nimityksiä islaminuskoinen tai muslimi mainita koko aineistossa kertaakaan. Aineistossa on selviä viittauksia islaminuskoon vain vähän, ${ }^{10}$ mutta tästä huolimatta perussuomalaiset, kristillisdemokraatit ja kokoomus näyttävät yhdistävän islamin turvallisuusuhkiin, ennen kaikkea terrorismiin. Vaalien alla mediassa ja julkisessa keskustelussa käsiteltiin paljon ääriislamistista Isis-järjestöä ja sen aiheuttamaa turvallisuusuhkaa Euroopassa. Erityisen paljon huomiota herätti niin kutsuttu vierastaistelija-ilmiö, jolla viitataan siihen, että ihmiset eri puolilta Eurooppaa matkustavat sota-alueille liittyäkseen esimerkiksi Isisin joukkoihin (ks. Sisäministeriö 2014a). Kaikki turvallisuusdiskurssia hyödyntävät puolueet käsittelevät teemaa vaalimateriaaleissaan, kuten kristillisdemokraatit seuraavassa esimerkissä:

10. Tällaisia selviä viittauksia ovat perussuomalaisten käyttämä ilmaus jihad-turismi ja kristillisdemokraattien vaaliohjelman ääri-islamiin perustuva terrorismi. 
(14) Terrorismintorjunta on noussut nopeasti tärkeäksi osaksi poliisin työtä, ja lainsäädäntöä on uudistettu vastaamaan muuttunutta ja voimakkaasti kansainvälistynyttä toimintaympäristöä. Suojelupoliisin toimivaltuuksia tulee tarvittaessa täydentää sen varmistamiseksi, että se pystyy tehokkaasti torjumaan terroristisia rikoksia ja radikalisoitumista.

(KD)

Esimerkissä 14 ei liitetä terroristisia rikoksia ja radikalisoitumista suoraan mihinkään ihmisryhmään. Esimerkissä on kuitenkin kielellisiä valintoja, jotka aktivoivat mahdollisen tulkinnan, ettei puhe ole kenestä tahansa vaan erityisesti islaminuskoisista ihmisistä. Yhteys maahanmuuttoon syntyy ennen kaikkea sanastollisista valinnoista. Ensinnäkin käsitettä radikalisoituminen - etenkin yhdistettynä terrorismin uhkaan - on tekstin laatimisen aikaan käytetty julkisessa keskustelussa hyvin spesifissä merkityksessä. Mediassa radikalisoitumisesta on puhuttu käsiteltäessä erityisesti terroritekoja sekä ääri-islamistisen Isis-järjestön värväystoimintaa, jonka myötä myös Suomesta on matkustanut ihmisiä Isisin hallitsemille alueille Lähi-itään. Kun otetaan huomioon ne käyttöyhteydet, joissa käsite vaalikampanjoinnin aikaan usein on esiintynyt, radikalisoitumisen voi olettaa herättävän monessa lukijassa konnotaation islamiin ja muslimeihin. ${ }^{11}$ Jos kristillisdemokraatit olisi halunnut välttää tämän tulkinnan, tekstissä olisi todennäköisesti tehty toisenlaisia kielellisiä valintoja. Vaikka ihmisryhmää ei suoraan nimettäisi, pelkkä tietyn toiminnan konstruoiminen voi implikoida, keistä on puhe (Jokinen, Juhila \& Suoninen 2012: 63-64).

Toiseksi esimerkin 14 kuvaus muuttuneesta ja voimakkaasti kansainvälistyneestä toimintaympäristöstä sekä terrorismintorjunnan noususta nopeasti tärkeäksi osaksi poliisin työtä rakentaa kuvaa äkillisestä muutoksesta turvallisuusympäristössä. Tämä puoltaa tulkintaa, että esimerkissä käsitellään Isisiä, joka onnistui eduskuntavaaleja edeltävän vuoden 2014 aikana saamaan nopeasti haltuunsa laajoja alueita Irakissa ja Syyriassa. Poliisin toimintaympäristön kuvaaminen kansainvälistyneeksi kertoo, että terrorismilla tarkoitetaan valtioiden rajat ylittävää toimintaa. Toisaalla vaaliohjelmassaan kristillisdemokraatit puhuu eksplisiittisesti ääri-islamiin perustuvasta terrorismista. Yhteyttä ei kuitenkaan esimerkissä 14 eksplikoida, eikä siinä myöskään rajata kielellisillä valinnoilla ei-muslimeja mahdollisen tulkinnan ulkopuolelle. Sama koskee myös esimerkkiä 15, jossa ehdotetaan, että niin kutsuttua vierastaistelija-ilmiötä tulisi suitsia kriminalisoimalla ulkomaille terroristiseen toimintaan lähteminen:

(15) Kynnystä lähteä ulkomaille terroristiseen toimintaan nostetaan kieltämällä se tarvittaessa lailla.

(Kok.)

11. Esimerkiksi Helsingin Sanomien verkkosivujen hakutoiminnon kautta hakusanalla radikalis* löytyy aikavälillä 4.3.2014-4.3.2015 lehden pääkirjoitus-, kotimaan- ja ulkomaanosastoilta yhteensä 136 hakutulosta, joista laskujeni mukaan 128:ssa radikalisoituminen yhdistetään islamiin tai muslimeihin. 
Kokoomuksen linjaa ilmentävässä esimerkissä 15 yhteyttä maahanmuuttoon ei tekstin tasolla eksplikoida, mutta sisällöltään se vertautuu esimerkkiin 14, joka on siis kristillisdemokraattien vaaliohjelmasta. Kun esimerkissä 15 esitetään, että kynnystä matkustaa ulkomaille terroristisessa tarkoituksessa tulisi nostaa, implikoidaan samalla, että nykytilanteessa se on liian helppoa. Tämä taas yhdistyy vaalien alla ajankohtaiseen keskusteluun siitä, edellyttääkö lisääntynyt matkustaminen erityisesti Isisin hallitsemille konfliktialueille lainsäädännöllisiä muutoksia (esim. Sisäministeriö 2014b). Mitenkään yksiselitteisesti puhe ei tässäkään tapauksessa ole maahanmuuttajataustaisista ihmisistä. Sikäli kun esimerkeissä 14 ja 15 on puhe islaminuskoisista, uhkarepresentaation voi tulkita koskevan myös syntyperäisiä suomalaisia, jotka ovat uskonnolliselta vakaumukseltaan muslimeja. Valtaosa Suomessa elävistä muslimeista kuitenkin on maahanmuuttajataustaisia, minkä myötä uhkarepresentaatio koskee potentiaalisesti erityisesti heitä ja välillisesti myös kaikkia sellaisia ihmisiä, jotka oletetaan muslimeiksi esimerkiksi syntyperänsä perusteella. Sillä, ettei ihmisryhmiä eksplikoida, voidaan pyrkiä välttämään ihmisten leimaamista. Aineistossa maahanmuutto merkityksellistetään turvallisuusuhaksi usein epäsuorasti esimerkiksi presuppositioiden ja implikaatioiden avulla, jolloin voidaan puhua Wodakia (2015a: 46-47, 50) mukaillen avoimen diskriminoivia ilmauksia välttelevästä koodatusta puhetavasta (coded language).

Yksi selitys koodatun puhetavan suosiolle aineistossani voi löytyä länsimaissa 1900luvun hirmutekojen myötä kielenkäyttöön iskostuneesta normista, jonka mukaan ihmisryhmien avoin leimaaminen ei ole hyväksyttävää (Wodak 2015a: 46). Vaikka kielenkäyttö ei olisi avoimen diskriminoivaa, sillä voi silti olla puheena olevien ihmisryhmien kannalta epäsuotuisia vaikutuksia. Turvallisuusdiskurssissa uhat liitetään tiettyihin ihmisryhmiin, kuten muslimeihin, Romanian ja Bulgarian romaneihin sekä kaksoiskansalaisiin. Tämä on keino legitimoida diskursiivisesti eri ihmisryhmien välistä eriarvoisuutta. Viime aikoina Euroopassa ja Yhdysvalloissa tehdyt poliittiset päätökset osoittavat, että esimerkiksi islaminuskoisten ihmisten aseman heikentämistä voidaan perustella vetoamalla heidän aiheuttamaansa potentiaaliseen turvallisuusuhkaan. Kun painotetaan voimakkaasti turvallisuusnäkökulmaa, kysymys uhaksi representoitujen ihmisten yksilöllisyydestä ja oikeuksista muuttuu toisarvoiseksi. Pelkoa käytetään välineenä legitimoida haluttuja poliittisia toimenpiteitä (mt.).

\subsection{Nationalistinen diskurssi}

Nationalistisessa diskurssissa Suomi näyttäytyy homogeenisenä yhteiskuntana, jonka yhtenäisyyttä, kulttuuria ja arvoja (etenkin ei-länsimaalainen) maahanmuutto uhkaa. Maahanmuutto esitetään lähtökohtaisesti ei-toivottavana, normaalista poikkeavana ja hallintaa vaativana ilmiönä. Turvallisuusdiskurssin tapaan myös nationalistisessa diskurssissa maahanmuutosta rakentuu uhkaava kuva. Näiden kahden diskurssin erottaminen toisistaan on joskus vaikeaa, ja aineistossa ne risteävätkin usein jopa saman virkkeen sisällä. Pääasiallinen ero on siinä, että turvallisuusdiskurssista poiketen nationalistisessa diskurssissa konstruoidut uhkakuvat eivät ole konkreettisia vaan pikemminkin symbolisia. Nationalistinen diskurssi on erityisesti perussuomalaisten suosima puhetapa. Myös kristillisdemokraatit hyödyntää tätä diskurssia mutta vain marginaalisesti. 
Nationalistisessa diskurssissa kiinnitetään huomiota maahanmuuttajien määrään ja maahanmuuton kasvuvauhtiin. Tilastojen ja lukujen esittämisellä voi tekstissä olla monia eri funktioita, eikä niihin viittaaminen rajoitu vain nationalistiseen diskurssiin. Näennäisen neutraaleina numerot tuovat objektiivisuuden tuntua, mistä syystä niitä on suosittu erityisesti tiedonvälityksessä. Se, mitä informaatiota esitetään kvantifioidussa muodossa, on kuitenkin ideologinen valinta, ja maahanmuuttoa käsiteltäessä korostetaan usein juuri maahanmuuttajien lukumäärää sekä maahanmuuttoon liittyvien kulujen suuruutta. (Kalliokoski 1995b: 85-88; ks. myös Blomqvist 1995: 135-136; Pietikäinen 200ob: 159-163.) Esimerkissä 16 lukuja käytetään korostamaan maahanmuuton suuruutta:

(16) Suomessa asuu tällä hetkellä jo noin 300 ooo ulkomaalaistaustaista ihmistä, mikä vastaa 5,5 \% osuutta kokonaisväestöstä. Vuosittainen nettomaahanmuutto on kymmenessä vuodessa kohonnut lähes 20 tuhanteen ilman, että politiikka olisi reagoinut tähän millään tavalla.

(PS: Mp.)

Esimerkissä 16 maahanmuuttoa hahmotetaan lukumäärien näkökulmasta ja tilastoihin ja lukuihin keskittymällä luodaan kuva, että olisi olemassa normaalitilanne, jossa maahanmuuttoa ei ole. Vastaavanlaisia huomioita lukujen käytöstä on tehnyt Kalliokoski (1995b: 87). Kun kaikki Suomessa asuvat ulkomaalaistaustaiset ihmiset niputetaan tähän tapaan yhdeksi ryhmäksi, maahanmuuton syyt ja ihmisten taustojen ja tilanteiden yksilöllisyys jäävät taka-alalle. Luvut itsessään eivät luonnollisesti johda politiikkasuosituksiin, mutta niiden esiin nostaminen antaa ymmärtää, että niissä on jotain huomionarvoista, kenties hälyttävääkin. Tätä korostaa adverbi jo, joka vahvistaa mielikuvaa ulkomaalaistaustaisten ihmisten määrän suuruudesta. Lisäksi esimerkissä kerrotaan vuosittaisen nettomaahanmuuton eli maahanmuuton ja maastamuuton erotuksen nousseen lähes 20 tuhanteen. ${ }^{12}$ Vaikka nettomaahanmuutto itsessään ei kerro mitään siitä, millaiset ihmiset muuttavat Suomesta tai Suomeen tai mistä syistä ihmiset muuttavat, maahanmuuton ja maastamuuton suhteen implikoidaan olevan tällaisenaan ongelmallinen: nettomaahanmuuton todetaan kohonneen nykyiselle tasolleen ilman, että politiikka olisi reagoinut tähän millään tavalla. Ongelmallisuutta painotetaan myös käyttämällä ajanmäärettä kymmenessä vuodessa, jolla korostetaan muutoksen äkillisyyttä. Ilmeinen tulkinta (ja muualla maahanmuuttopoliittisessa ohjelmassa eksplikoitu kanta) on, että perussuomalaisten mielestä maahanmuuttopolitiikkaa pitäisi kiristää.

Nationalistisessa diskurssissa puhutaan paitsi maahanmuuton haitallisuudesta myös suomalaisuudesta ja sen erityislaatuisuudesta, jota tulee suojella. Ihmisoikeusdiskurssista poiketen suomalaisuudesta rakennetaan kuvaa suljettuna ja valtaväestön kontrolloimana ryhmäkategoriana, jonka kriteerejä maahanmuuttaja ei ehkä koskaan

12. Merkille pantavaa on, että nettomaahanmuutossa näkökulma on paitsi Suomeen muuttavissa myös Suomesta pois muuttavissa ihmisissä. Tällainen laajempi siirtolaisuuden näkökulma on aineistossa verrattain harvinainen. 
täytä. Diskurssissa suomalaisuus on jotain itsestään selvää, kyseenalaistamatonta ja luonnollista, eikä aineistossa ole tarkkaa suomalaisuuden määritelmää. Olennaista vaikuttaa olevan se, miten "me suomalaiset" eroamme maahanmuuttajista. Diskurssissa hyödynnetään kahta toisiaan täydentävää diskursiivista strategiaa (Wodak 2015a: 5152): myönteistä itsen esittämistä (positive self-presentation) ja kielteistä toisen esittämistä (negative other-presentation), mikä käy ilmi esimerkiksi seuraavasta:

(17) Miljoona suomalaista elää köyhyysrajalla tai sen alapuolella. Pienituloisuus vaikuttaa koko elämään ja sen valintoihin. Mielivaltaiset leikkaukset on loputtava ja 90 - luvun laman virheitä ei tule enää toistaa. Suomalaisista on ryhdyttävä nyt huolehtimaan. Meidän ei kuulu olla koko maailman terveyskeskus tai sosiaalitoimisto.

(PS: Vo.)

Esimerkin 17 alussa käsitellään suomalaisia koskevaa vaikeaa taloudellista tilannetta. Nationalistinen maahanmuuttodiskurssi aktivoituu, kun esimerkissä luodaan vastakkainasettelu suomalaisten ja koko maailman välille. Persoonapronomini me ilmentää kirjoittajan sitoutumista kategoriaan suomalaiset, mistä seuraa, että suomalaiset rakentuu sisäryhmäkategoriaksi. Suomalaisten implisiittiseksi vastakohdaksi ja samalla ulkoryhmäksi asettuu koko maailma, jonka voi tulkita viittaavan kaikkiin muihin paitsi suomalaisiin - erityisesti Suomeen tulleisiin tai tuleviin maahanmuuttajiin tai näihin molempiin ryhmiin. Ulkoryhmäkonstruktiolle tyypilliseen tapaan ryhmä esitetään kielteisessä valossa: ilmauksella koko maailman terveyskeskus tai sosiaalitoimisto rakennetaan kuvaa, jonka mukaan Suomeen halutaan tulla erityisesti palveluiden ja etujen motivoimina. Kontrasti on suuri verrattuna esimerkin suomalaisiin, jotka kuvataan leikkauspolitiikan uhreina. (Ks. sisä- ja ulkoryhmäkategorisaation kielellisestä rakentumisesta Pälli 2003.)

Esimerkissä 17, joka on perussuomalaisten vaaliohjelmasta, karrikoidaan liioittelun keinoin muiden puolueiden maahanmuuttopolitiikkaa implikoimalla, että joidenkin tahojen mielestä Suomen tulisi olla koko maailman terveyskeskus tai sosiaalitoimisto (ks. kieltolauseen intertekstuaalisuudesta Fairclough 1992: 121-122). Myös muualla vaalimateriaaleissaan perussuomalaiset rakentaa kuvaa poliittisista vastustajistaan täysin sääntelemättömän maahanmuuton kannattajina, joihin puolue samalla tekee eroa. Edeltävästä esimerkistä käy ilmi, että perussuomalaiset asemoi itsensä nimenomaan suomalaisten puolustajaksi julistamalla, että suomalaisista on ryhdyttävä nyt huolehtimaan. Virkkeessä ajankohtaa ilmaiseva adverbi nyt sekä on tehtävä -nesessiivirakenne implikoivat, ettei suomalaisista aiemmin ole huolehdittu.

Nationalistisessa diskurssissa käsitellään myös kansalaisuutta. Nationalistista diskurssia hyödyntävät puolueet haluavat kiristää kansalaisuutta sääteleviä lakeja tai vähintään pitää kansalaisuuteen vaadittavat kriteerit ennallaan. Kansalaisuus on vallan näkökulmasta merkittävä kysymys, koska vasta kansalaisuus tuo mukanaan yhteiskunnan täysivaltaisen jäsenyyden siihen kuuluvine oikeuksineen ja velvollisuuksineen. Kaikki kansallisvaltiot rajoittavat lainsäädännöllä kansalaisuuden saamista, mikä osaltaan mahdollistaa institutionaalisen syrjinnän harjoittamisen (Wodak 2015b: 369). Kansalaisuuden kontrollointi on legitiimi ja usein kyseenalaistamaton keino pi- 
tää yllä valtajärjestystä, jossa kaikilla ihmisillä ei ole yhtäläisiä oikeuksia ja mahdollisuuksia vaikuttaa yhteiskunnassa. ${ }^{13}$ Esimerkistä 18 käy ilmi, miten kristillisdemokraatit käsittelee kansalaisuuden saamisen edellytyksiä sekä mahdollisuutta kiristää monikansalaisuutta koskevaa lainsäädäntöä:

(18) Suomen kansalaisuuden saamisen edellytyksenä tulee säilyä kotimaisen kielen hallitseminen. Muiden eurooppalaisten maiden toimenpiteitä monikansalaisuuden rekisteröimisen sekä esimerkiksi terrorismitapauksissa kansalaisuuden poistamisen suhteen tulee seurata aktiivisesti.

(KD)

Kristillisdemokraatit vaatii, että kansalaisuuden saamisen kriteerinä tulee säilyä kotimaisen kielen hallitseminen. Huomionarvoista on, että puhe kotimaisesta kielestä viittaa suomen kielen ohella mitä ilmeisemmin myös ruotsin kieleen, eikä näkökulma siten mukaile ahtaan nationalistista $y k s i$ kansa - yksi kieli - yksi valtio -ideologiaa. Esimerkki kuitenkin aktivoi nationalistisen diskurssin kytkiessään kansalaisuuden vahvasti kansalliskieliin. Esimerkissä ei eksplikoida, mitä kielen hallitsemisella tarkoitetaan eli millaista kielitaidon tasoa maahanmuuttajilta kansalaisuuden saamiseksi edellytetään. Nationalistiselle diskurssille tyypilliseen tapaan maahanmuuttajille esitettävät vaatimukset jäävät vaille tarkempia määritelmiä, mikä on tehokas väline ylläpitää maahanmuuttajien ja valtaväestön välisiä hierarkioita: kriteerit on aina mahdollista määritellä uudestaan, ja määrittelyvalta on valtaväestön käsissä (Blommaert \& Verschueren 1998: 111-114).

Esimerkissä 18 ei suoraan ehdoteta muutoksia kansalaisuutta sääteleviin lakeihin, vaan siinä sen sijaan todetaan, että asiassa tulee seurata aktivisesti muiden eurooppalaisten maiden toimenpiteitä. Nesessiivinen tulla-verbi esittää toiminnan kuitenkin pakottavana, ja esimerkki implikoi, että Suomen tulisi seurata muiden eurooppalaisten valtioiden esimerkkiä, jos ne kiristävät kansalaisuuslainsäädäntöään. Esimerkki on myös osoitus siitä, miten nationalistinen diskurssi usein kietoutuu turvallisuuspuheeseen: kansalaisuuden poistaminen voisi kristillisdemokraattien mukaan tulla kyseeseen esimerkiksi terrorismitapauksissa, mikä aktivoi turvallisuusdiskurssin (ks. alalukua 4.3).

Nationalistisessa diskurssissa maahanmuutosta ja maahanmuuttajista käytetään usein yleisnimityksiä: aineistossa maahanmuuttajia kutsutaan esimerkiksi siirtolaisiksi, ulkomaalaistaustaisiksi ihmisiksi ja tulijoiksi. Symbolinen uhka ei näytäkään palautuvan tiettyihin ihmisryhmiin sinänsä vaan pikemminkin maahanmuuttoon yleisesti. Aineistossa kuitenkin on tekstiä, jossa maahanmuuttajien joukosta kategorisoidaan tarkemmin rajattuja, erityisen uhkaavina pidettyjä ryhmiä. Esimerkissä 19 uhkaa edustaa ennennäkemätön siirtolaispaine Afrikasta ja Lähi-idästä:

13. Vaikka puolueista vain perussuomalaiset ja kristillisdemokraatit hyödyntävät maahanmuutosta puhuessaan nationalistista diskurssia, yksikään puolue ei ohjelmassaan kyseenalaista kansallisvaltion kehystä, saati irtisanoudu siitä. Kaikilla puolueilla kansallisvaltio on implisiittinen ja ideologinen lähtökohta, josta käsin maahanmuuttoa tarkastellaan. 
(19) Eurooppaan kohdistuu tällä hetkellä ennennäkemätön siirtolaispaine Afrikasta ja Lähi-Idästä. - - Eurooppa, etenkin Pohjois-Euroopan hyvinvointivaltiot, on avokätisine sosiaaliturvajärjestelmineen houkutteleva kohde myös sellaisille siirtolaisille - - jotka eivät uskonnollisista ja kulttuurisista syistä halua omaksua integraation kannalta tärkeitä eurooppalaisia käsityksiä esimerkiksi tasa-arvosta tai ilmaisunvapaudesta.

(PS: Mp.)

Ilmaus eurooppalaisia käsityksiä esimerkiksi tasa-arvosta tai ilmaisunvapaudesta sisältää presupposition, jonka avulla yhteisten, eurooppalaisten käsitysten olemassaolo esitetään varmana. Lisäksi esimerkissä kuvataan kyseenalaistamattomana tosiseikkana se, että osa maahanmuuttajista ei jaa näitä käsityksiä: he eivät uskonnollisista ja kulttuurisista syistä halua omaksua niitä. Esimerkissä rakennetaan kuvaa eurooppalaisten ja Euroopan ulkopuolelta tulevien maahanmuuttajien eriävistä käsityksistä esimerkiksi tasa-arvon ja ilmaisunvapauden suhteen. Eronteon lisäksi erilaisiksi koettuja käsityksiä (ja siten myös ihmisryhmiä) arvotetaan implikoimalla, että eurooppalaiset käsitykset ovat parempia maahanmuuttajien vastaaviin verrattuna. Näin esimerkissä samanaikaisesti rakennetaan myönteistä kuvaa "meistä" eurooppalaisista (ja samalla suomalaisista) ja kielteistä kuvaa "toisista” ei-eurooppalaisista. Tämän kuvan mukaan sopeutumattomia ja siten ei-toivottuja maahanmuuttajia ovat Pohjois-Afrikasta tai Lähiidästä lähtöisin olevat, uskontokunnaltaan ei-kristityt ja kulttuuriperimältään ei-länsimaalaiset siirtolaiset, jotka muuttavat maahan paremman elintason toivossa. Sekä eurooppalaiset että Eurooppaan tulevat siirtolaiset kuvataan homogeenisinä joukkoina, joiden arvomaailmat eivät ole yhteensovitettavissa.

Esimerkin 19 mukaan eurooppalaiset käsitykset tasa-arvosta ja ilmaisunvapaudesta ovat maahanmuuttajien integraation kannalta tärkeitä. Näin eurooppalaisten käsitysten omaksuminen asetetaan onnistuneen integroitumisen edellytykseksi. Nationalistiselle diskurssille on tyypillistä asettaa maahanmuuttajille joko implisiittisesti tai suoraan vaatimus sopeutua suomalaiseen yhteiskuntaan, kulttuuriin ja arvoihin, joille ei kuitenkaan anneta aineistossa eksplisiittisiä määritelmiä. Niinpä käsitteet voidaan määritellä aina kulloiseenkin tilanteeseen sopivasti niin, että määrittely palvelee valtaväestön etuja. Siinä missä maahanmuuttajille voidaan asettaa aina uusia vaatimuksia, jotka heidän tulee täyttää osoittaakseen kotoutuneensa tai integroituneensa yhteiskuntaan, valtaväestöä samanlaiset vaatimukset eivät koske (Blommaert \& Verschueren 1998: 13, 113-114).

Esimerkissä 19 esitetään väitteitä maahanmuuttajien sisäisestä maailmasta: motiiveista, arvoista ja haluista. Kun Pohjois-Euroopan hyvinvointivaltioita kuvataan maahanmuuttajien näkökulmasta houkuttelevaksi kohteeksi avokätisine sosiaaliturvajärjestelmineen, siirtolaisuuden motiiviksi esitetään taloudellinen hyöty - ja nimenomaan sosiaaliturvan, ei työstä maksettavan palkan muodossa. Lisäksi esimerkissä on koko aineistossa harvinainen maahanmuuttajien sisäisen maailman kuvaus. Heidän tunteistaan tehdään yleistys käyttämällä mentaalista verbi haluta: [sellaiset siirtolaiset] eivät uskonnollisista ja kulttuurisista syistä halua omaksua integraation kannalta tärkeitä eurooppalaisia käsityksiä - -. Konstruoidulle maahanmuuttaja- 
ryhmälle rakentuu kollektiivinen mieli, minkä myötä haluttomuus omaksua (implisiittisesti parempia ja vaalimisen arvoisia) käsityksiä ja siten integroitua muodostuu tämän ryhmän ryhmäominaisuudeksi (ks. Pälli 2003: 227). Samalla vastuu integroitumisesta sysätään yksinomaan maahanmuuttajien itsensä vastuulle: jos siirtolaiset eivät halua kotoutua, kysymys vastaanottavan valtion, kuntien ja kansalaisten roolista ei ole relevantti. Esimerkin 19 rakentaman kuvan perusteella kotoutumista ei voi edesauttaa asenneilmapiirin muutoksilla tai maahanmuuttopoliittisilla toimilla - siksi nationalistisen diskurssin maailmankuvassa maahanmuuton rajoittaminen näyttäytyy järkevänä maahanmuuttopolitiikkana. Vetoamalla epäonnistuneeseen kotoutumiseen Suomessa jo olevilta maahanmuuttajilta voidaan evätä oikeuksia, jotka itsestään selvästi kuuluvat muulle väestölle (vrt. Martínez Guillem 2017).

\section{Lopuksi}

Päätösluvussa kokoan yhteen analyysin tuloksia ja suhteutan niitä aiempaan tutkimukseen. Diskurssien jaotteluun liittyy aina valintoja, joita teen näkyväksi esittelemällä myös vaihtoehtoisia tulkintamahdollisuuksia. Lopuksi suuntaan katseen eteenpäin ja pohdin tutkimuksen avaamia tulevaisuudennäkymiä: millaisista näkökulmista (kriittisen) diskurssintutkimuksen olisi jatkossa hedelmällistä tarkastella yhteiskunnallista maahanmuuttokeskustelua?

\subsection{Toteutuneet, mahdolliset ja mahdottomat diskurssit}

Olen analysoinut eduskuntapuolueiden kevään 2015 vaaliohjelmien maahanmuuttoaiheisia osia sekä lisäksi perussuomalaisten maahanmuuttopoliittista ohjelmaa ja tunnistanut aineistosta neljä eri diskurssia, joita kutsun talous-, ihmisoikeus-, turvallisuusja nationalistiseksi diskurssiksi. Kaikkia diskursseja hyödyntää vähintään kaksi puoluetta. Talousdiskurssi edustaa aineistossa hegemonista merkityksellistämisen tapaa: kaikki eduskuntapuolueet käyttävät sitä vaaliohjelmassaan, osa tosin vain marginaalisesti. Tätä voi pitää osoituksena talousnäkökulman sosiokulttuurisesta voimasta, joka houkuttelee puolueita omaksumaan puhetavan läpi poliittisen kentän. Vaikka taloudellisen näkökulman korostumiseen on kiinnitetty huomiota jo pitkään (esim. Fairclough 2001a), tutkimukseni tarjoaa uutta tietoa talousdiskurssin hegemonisesta asemasta suomalaisessa politiikassa.

Aineistossa on kaksi diskurssia, joiden sisällä maahanmuutto representoidaan yksinomaan ei-toivotuksi ilmiöksi: Turvallisuusdiskurssissa maahanmuutto yhdistetään konkreettisiin turvallisuusuhkiin, kuten rikollisuuteen ja terrorismiin, ja maahanmuuttajista rakennetaan kuvaa aktiivisina toimijoina, joiden teot aiheuttavat turvattomuutta. Tässä diskurssissa maahanmuutto merkityksellistetään uhaksi myös epäsuorasti hyödyntämällä esimerkiksi radikalisoitumisen tapaisia, kulttuurisesti latautuneita käsitteitä. Nationalistisessa diskurssissa symbolinen uhka juontuu maahanmuuttajien oletetusta sopeutumattomuudesta suomalaiseen yhteiskuntaan. Erityisesti länsimaiden ulkopuolelta tuleva maahanmuutto kuvataan epätoivottavana, jopa luon- 
nottomana. Tyypillisiä diskursiivisia strategioita ovat myönteinen itsen esittäminen ja kielteinen toisen esittäminen. Aineistossa sekä turvallisuusdiskurssin että nationalistisen diskurssin voi katsoa toimivan ideologisesti niin, että rakentamalla maahanmuutosta hyvin kielteistä kuvaa ne uusintavat ja tuottavat yhteiskunnallista järjestystä, jossa maahanmuuttajat eivät ole yhdenvertaisia valtaväestön kanssa. Molemmat diskurssit liittyvät laajempiin eurooppalaisiin kehityssuuntiin. Esimerkiksi turvallisuusdiskurssissa konstruoitu islamin uhka on yleinen teema erityisesti äärioikeistolaisten ja oikeistopopulististen puolueiden kannanotoissa (ks. esim. Krzyżanowski 2013; Wodak 2015a); nationalistisen diskurssin voi puolestaan yhdistää nationalistisen populismin nousuun länsimaissa (ks. esim. Gusterson 2017). Ei ole yllättävää, että puolueet eri puolella Eurooppaa hyödyntävät samanlaisia puhetapoja, sillä puolueet ovat verkottuneita toisiinsa jo Euroopan unionin kautta eikä maahanmuuttopoliittista keskustelua käydä tyhjiössä.

Aineistossani hegemonisia valtasuhteita haastamaan asettuu ihmisoikeusdiskurssi, jossa vedotaan kaikille kuuluviin ihmisoikeuksiin ja vastuunkantoon maahanmuuton oikeuttamiseksi. Hegemonisia valtasuhteita potentiaalisesti purkavista puhetavoista on tehty kielitieteellistä tutkimusta toistaiseksi vasta vähän. Blommaert ja Verschueren (1998: 107-109) ovat kiinnittäneet huomiota siihen, että ihmisoikeuksien korostaminen voi paradoksaalisesti olla väline diskriminoida maahanmuuttajia, joiden ei katsota jakavan samoja arvoja. Tarvittaisiinkin tarkempaa tietoa siitä, miten ja mihin tarkoituksiin ihmisoikeusdiskurssia eri konteksteissa käytetään. Tämän tutkimuksen aineistossa ihmisoikeusdiskurssissa viitataan ihmisiin usein geneerisillä nimityksillä, jotka eivät sulje ketään ryhmän ulkopuolelle. Diskurssissa konstruoidaan myös tarkemmin rajattuja ryhmiä, joiden tilanteen parantamiseksi ehdotetaan konkreettisia politiikkatoimenpiteitä. Suuri osa ihmisoikeusdiskurssista on kuitenkin abstraktia arvopuhetta. Toisin kuin aineiston muissa diskursseissa, ihmisoikeusdiskurssissa näkökulma ei ole siinä, millaiset maahanmuuttajat ovat Suomelle hyödyksi tai haitaksi. Siinä ei kuitenkaan representoida maahanmuuttoa varsinaisesti toivottavaksi ilmiöksi.

Maahanmuutto näyttäytyy toivottavana ainoastaan talousdiskurssissa, ja silloinkin puhe on pääasiassa työ- ja opiskeluperäisestä maahanmuutosta. Talousdiskurssin voi nähdä vahvistavan suhtautumistapaa, jossa maahanmuuton oikeutus syntyy sen myönteisestä vaikutuksesta kansantalouteen (ks. Wodak 2015a: 85-86). Diskurssille tunnusomaista ovat esimerkiksi välttämättömyyttä ilmaisevien modaalisten kielenainesten käyttö, inhimillisten toimijoiden häivyttäminen sekä talouden ilmiöiden esittäminen kyseenalaistamattomina tosiasioina. Diskurssia hyödynnetään perusteltaessa opiskeluja työperäisen maahanmuuton helpottamista, mutta maahanmuuttajien aseman kannalta olennaista on, että taloudelliset argumentit soveltuvat myös tiettyjen maahanmuuttajien ulossulkemisen välineeksi. Turvallisuusdiskurssin ja nationalistisen diskurssin ohella aineistossa käytetään myös talousdiskurssia legitimoimaan maahanmuuton tiukempaa sääntelyä ja uusintamaan hierarkkista valtajärjestystä.

Diskurssiluokittelu ei ole absoluuttinen: diskurssit risteävät aineistossa, ja niissä voi nähdä myös päällekkäisyyksiä. Tunnistamani diskurssit eivät ole myöskään ainoa mahdollinen tulkinta. Analyysivaiheessa olen pohtinut muun muassa sitä, olisiko perusteltua puhua turvallisuusdiskurssin ohella erillisestä lakidiskurssista ja olisiko humanitaa- 
rinen diskurssi ollut ihmisoikeusdiskurssia kuvaavampi nimitys. Lisäksi olen pohtinut, voisiko aineistossa usein toistuvan teeman maahanmuuttojärjestelmän hyväksikäytöstä käsittää omaksi diskurssikseen. ${ }^{14}$ Aineistossa esitetään taajaan vihjailuja ja syytöksiä, joiden mukaan maahanmuuttajat tulevat Suomeen tekaistuin perustein, käyttävät hyväksi sosiaaliturvajärjestelmää eivätkä halua osallistua yhteiskunnan rakentamiseen. Erityisesti humanitaaristen maahanmuuttajien motiivien kyseenalaistaminen on aineistossa yleinen diskursiivinen strategia, jolla maahanmuuton tiukempi sääntely pyritään legitimoimaan. En kuitenkaan ole nimennyt erillistä "huijaridiskurssia", sillä teema saa aineistossa erilaisia ilmiasuja: väitteet järjestelmän hyväksikäytöstä kytkeytyvät kysymyksiin kansantaloudellisesta haitasta (talousdiskurssi) sekä konkreettisista (turvallisuusdiskurssi) ja symbolisista (nationalistinen diskurssi) uhista.

Myös rasistisen diskurssin mahdollisuutta on syytä pohtia. On selvää, että etenkin turvallisuusdiskurssissa ja nationalistisessa diskurssissa sekä osin talousdiskurssissa maahanmuuttajista luodaan kollektiivina voimakkaan kielteistä kuvaa. Aineistossa ei ole "rotuun" pohjautuvaa vanhaa rasismia, mutta uusrasistisia piirteitä siinä voi nähdä (ks. vanhan rasismin ja uusrasismin eroista esim. van Dijk 20oo; rasismin määritelmistä Puuronen 2011: 53-66). Aineistosta ei kuitenkaan erotu sellaista yhtenäistä leksikkokieliopillista kokonaisuutta, jota olisi mielekästä nimittää rasistiseksi diskurssiksi. Vaikka aineistossa on myös avoimen leimaavaa kielenkäyttöä, kielteistä kuvaa maahanmuuttajista luodaan usein epäsuorasti. Aineiston rasistisuuden määrittelemistä olennaisempaa on nähdäkseni se, miten aineisto osallistuu rasististen ja syrjivien käytänteiden tuottamiseen ja ylläpitämiseen. Aineistossa on elementtejä, jotka paitsi rakentavat hyvin kielteistä kuvaa joko maahanmuuttajista yleensä tai jostain rajatummista maahanmuuttajaryhmistä myös legitimoivat heihin kohdistuvia syrjiviä asenteita ja käytänteitä. On sinänsä toissijaista, pohjautuvatko representaatiot käsityksille kollektiivisista "roduista", kulttuureista, uskonnoista vai muista tekijöistä. Olennaista kielenkäytön vaikutusten näkökulmasta on se, että kielteiset ominaisuudet esitetään leimallisina kokonaisille ihmisryhmille.

Kriittisen diskurssintutkimuksen perinteeseen kuuluu pohtia toteutuneiden kielellisten valintojen ohella myös sitä, mitä aineistossa ei ole (Fairclough 1997: 30). Millä muulla tavoin maahanmuuttoa olisi mahdollista merkityksellistää? Tämän tutkimuksen näkökulmasta erityisen kiinnostavia ovat diskurssit, joilla epäsymmetrisiä valtasuhteita voisi haastaa. Aineistossa on marginaalisesti kohtia, joissa maahanmuutto esitetään luonnollisena tai ihmisille tunnusomaisena ilmiönä. Hyvin harvinaista on myös maahanmuuton tai monikulttuurisuuden representoiminen itsessään arvokkaaksi tai toivottavaksi asiaksi - maahanmuuttoa puolustetaan taloudellisen hyödyn ja vastuunkannon, ei moninaisuuden nimissä. Selityksiä moninaisuus itseisarvona -diskurssin marginaalisuudelle tai puuttumiselle voi etsiä esimerkiksi yhteiskunnan koventuneesta ilmapiiristä ja maahanmuuttajataustaisen äänestäjäkunnan pienuudesta. Maahanmuuttajat ovat myös edelleen marginaalisesti edustettuina suomalaisessa politiikassa. Osin tästä syystä Suomeen muualta muuttaneet eivät todennäköisesti ole merkittävissä

\footnotetext{
14. Pietikäinen (2000b: 161-162) on tunnistanut samankaltaisen diskurssin etnisen eron tuottamista käsittelevässä tutkimuksessaan.
} 
määrin päässeet vaikuttamaan siihen, miten maahanmuuttoa vaaliohjelmissa käsitellään.

\subsection{Yhteiskunnallinen maahanmuuttokeskustelu tutkimuksen kohteena nyt ja tulevaisuudessa}

Viime vuosina kriittisen diskurssintutkimuksen painopiste on ollut maahanmuuttovastaisissa liikkeissä ja puolueissa, jotka ovat kasvattaneet kannatustaan ympäri Eurooppaa (esim. Richardson \& Colombo 2014; Hatakka, Niemi \& Välimäki 2017; Wodak 2014, 2017). Vähemmän on tutkittu toimijoita, joiden kannat maahanmuuttoon eivät ole yhtä tunnettuja ja ennalta arvattavia. Silloinkin, kun tutkimuksissa on kartoitettu maahanmuuttopuhetta laajemmin, fokus on usein ollut syrjivissä ja rasistisissa puhetavoissa (esim. van Dijk 1997a; Wodak \& van Dijk toim. 2000). Tämän tutkimuksen aineistossa ovat edustettuna kaikki eduskuntapuolueet, ja analyysissa olen nostanut esiin myös sellaisia puhetapoja, joilla hierarkkisia valtasuhteita vastustetaan. Perussuomalaisilta on selvästi eniten aineistoa, mutta olen kokenut tärkeäksi tutkia myös muiden puolueiden kielenkäyttöä. Yksikään tunnistamani diskurssi ei ole vain yhden puolueen hyödyntämä, mutta samaan aikaan on syytä huomioida, että aineistossa nationalistinen diskurssi on leimallisesti perussuomalaisten suosima puhetapa. Vaikka perussuomalaisten ohjelmat eroavat tutkimuksen muusta aineistosta myös kovan retoriikkansa vuoksi, perussuomalaiset ei kuitenkaan ole ainoa puolue, joka rakentaa ohjelmissaan kielteistä kuvaa maahanmuutosta. Myös suvaitsevaisuutta ja kansainvälisyyttä korostavien puolueiden puhetavat voivat konstruoida hierarkioita maahanmuuttajien ja valtaväestön välille (ks. Blommaert \& Verschueren 1998; Martínez Guillem 2017). Tämä tutkimus onkin paljastanut yhteneväisyyksiä eri puolueiden tavoissa merkityksellistää maahanmuuttoa.

Toisaalta tutkimukseni tavoitteena on ollut tehdä näkyväksi puolueiden välisiä eroja ja merkityksistä käytävää kamppailua sekä sitä moninaisuutta, mitä suomalaisessa maahanmuuttopoliittisessa keskustelussa on. Kriittiseen tutkimusperinteeseen kuuluva pyrkimys edesauttaa myönteistä yhteiskunnallista muutosta velvoittaa tarkastelemaan kriittisesti paitsi analysoitavien aineistojen myös tutkimuspainotusten luomaa kuvaa todellisuudesta. Pahimmillaan keskittyminen maahanmuuttovastaisiksi oletettuihin tahoihin antaa todellisuudesta vääristyneen kuvan, mikä osaltaan voi olla vahvistamassa kuvaa maahanmuuttopolitiikan vaihtoehdottomuudesta. On myös syytä muistaa, että Suomen monipuoluejärjestelmässä yksikään puolue ei pääse yksin sane-

lemaan maahanmuuttopoliittisia linjauksia. Kaikki hallitusvastuussa olevat puolueet vähintään mahdollistavat tietynlaisen maahanmuuttopolitiikan toteuttamisen, mikä korostaa kaikkien puolueiden tutkimisen tärkeyttä.

Tämän tutkimuksen aineisto tarjoaa ikkunan yhteiskunnalliseen murroskohtaan. Aineiston ilmestymisen jälkeen maahanmuuton saralla on ehtinyt tapahtua paljon: turvapaikanhakijoiden määrän kasvun nojalla on ajettu läpi huomattavia kiristyksiä maahanmuuttopolitiikkaan, ja tapa puhua maahanmuutosta uhkana näyttää normalisoituneen politiikan diskurssissa ja kansalaiskeskustelussa (ks. Amnesty 2017). Kielitieteellistä tutkimusta puolueiden vaaliohjelmista ja tavoista merkityksellistää maahanmuuttoa on Suomessa tehty vielä vähän. Tämä tutkimus tarjoaa vertailukohdan sille, 
miten eduskuntapuolueiden kielenkäyttö maahanmuuton suhteen kehittyy. Jatkossa on tärkeää kartoittaa maahanmuuttopuheessa tapahtuneita muutoksia ja pohtia syitä eri puhetapojen suosiolle ja marginaalisuudelle. Tämä on kiinnostavaa niin lingvistisestä kuin yhteiskunnallisestakin näkökulmasta, sillä kielenkäytössä tapahtuvat muutokset ovat merkki laajemmasta yhteiskunnallisesta muutoksesta ja kielenkäytöllä on merkittävä rooli myös muutosten toteuttamisessa (Fairclough 1992).

Tutkimukseni on jatkumoa kriittisen diskurssintutkimuksen perinteelle, jossa katse kohdistetaan yhteiskunnallisten eliittien ja vallankäyttäjien kielenkäyttöön. Vaikka puolueet ja poliitikot ovat valta-asemansa ansiosta myös tulevaisuudessa erityisen tärkeitä tutkimuskohteita, katsantokantaa on syytä laajentaa poliittisen eliitin ulkopuolelle. Tarvetta ulottaa kriittisen diskurssintutkimuksen agenda vähemmistöjen ja kansalaisyhteiskunnan kielenkäyttöön on viime vuosina korostanut erityisesti positiviseksi diskurssianalyysiksi (positive discourse analysis) nimetty tutkimushaara, joka pyrkii tunnistamaan ja analysoimaan sosiaalista oikeudenmukaisuutta edistäviä puhetapoja (esim. Bartlett 2017). Tutkimusta maahanmuuttoaiheisesta kansalaiskeskustelusta ja ruohonjuuritason liikkeistä on tehtykin, mutta politiikan diskurssin tapaan tutkimus on keskittynyt maahanmuuttovastaisiin ääniin (ks. esim. Brindle 2016; Doerr 2017). Sen sijaan on olemassa vain vähän tutkittua tietoa siitä, millaisia diskursiivisia strategioita käytetään maahanmuuton puolustamiseen. Kansalaisyhteiskunnan kielenkäytön tutkiminen voi avata uusia näkökulmia maahanmuuttokeskustelun mahdollisuuksiin ja ehtoihin. Liikaa ei voi painottaa, miten tärkeää on kuulla tutkimuksessa myös maahanmuuttopuheen kohteena olevia ihmisiä eli maahanmuuttajia, joista jokaisella on oma yksilöllinen äänensä, tarinansa ja historiansa. Kriittisen diskurssintutkimuksen tehtävänä on tutkia, mitä he haluavat sanoa.

\section{Lähteet}

\section{Aineistolähteet ${ }^{15}$}

KD = Kristillisdemokraattien vaaliohjelma (29.11.2014). http://www.kd.fi/files/2015/o1/Eduskuntavaalit2015_vaaliohjelma.pdf.

Kesk. = Keskustan vaaliohjelma (7.2.2015). http://www.keskusta.fi/loader.aspx?id=9c181eco4d62-4e1f-a2a7-49138612043a.

Kok. = Kokoomuksen vaaliohjelma (6.2.2015). https://frantic.s3-eu-west-1.amazonaws.com/ kokoomus/Kokoomuksen_strateginen_hallitusohjelma.pdf.

PS: Mp. = Perussuomalaisten maahanmuuttopoliittinen ohjelma (5.2.2015). https://www.perussuomalaiset.fi/wp-content/uploads/2013/o4/ps-maahanmuuttopoliittinen_ohjelma_2015_ v3.pdf.

PS: Vo. = Perussuomalaisten vaaliohjelma (9.3.2015). https://www.perussuomalaiset.fi/wp-content/uploads/2015/03/ps_ek2015_vaaliohjelma_paateemat.pdf.

RKP = RKP:n vaaliohjelma (28.1.2015). http://www.sfp.fi/sites/default/files/Dokument/Program_fi/Vaaliohjelma.pdf.

15. Tekstien julkaisupäivämäärät merkitty sulkeisiin. 
SDP = SDP:n vaaliohjelma (23.11.2014). https://issuu.com/sosialidemokraatit_sdp/docs/vaaliohjelma2015.

Vas. = Vasemmistoliiton vaaliohjelma (26.11.2014). https://www.dropbox.com/s/pkw35osqxfb1wev/vaaliohjelma_suomi.pdf?dl=o.

Vihr. = Vihreiden vaaliohjelma (14.2.2015). https:/www.vihreat.fi/sites/default/files/vaaliohjelma2015.pdf.

\section{Kirjallisuuslähteet}

A ARnio, Eeva 1998: Päämäärät liikkeessä. Puolueohjelmien kirjoittamisen muuttuvat merkitykset Suomessa 1950-luvulta 1990-luvulle. Jyväskylä: Jyväskylän yliopisto.

Aarnio, Eeva - Kanerva, Jukna (toim.) 1995: Puolueohjelmatutkimuksen nykysuunnat. Jyväskylä: Jyväskylän yliopisto.

Aarnio, Eeva - Palonen, KARI (toim.) 1995: Puolueiden periaateohjelmat 1995. Jyväskylä: Jyväskylän yliopisto.

Amnesty 2014: "We ask for justice." Europe's failure to protect Roma from racist violence. https://www.amnesty.org/download/Documents/80oo/euro10o72014en.pdf (4.3.2018).

2017: Amnesty International report 2016/17. https://www.amnesty.org/download/Documents/POL1048002017ENGLISH.PDF (16.3.2018).

Bartlett, Tom 2017: Positive discourse analysis. - John Flowerdew \& John E. Richardson (toim.), The Routledge handbook of critical discourse studies s. 187-204. New York: Routledge.

Blommaert, Jan 2005: Discourse. A critical introduction. Cambridge: Cambridge University Press.

Blommaert, Jan - Verschueren, Jef 1998: Debating diversity. Analysing the discourse of tolerance. London: Routledge.

Blomqvist, Out i 1992: "Äkkiä mustat olivat Valkealassa." Pakolaiskeskustelun lingvististä analyysia. Suomen kielen pro gradu -tutkielma. Helsingin yliopisto.

— 1995: Mustien on määrä viipyä Valkealassa enintään kuukauden. Pakolaiset suomalaisissa sanomalehdissä. - Jyrki Kalliokoski (toim.), Teksti ja ideologia. Kirjoituksia kielestä ja vallasta julkisessa kielenkäytössä s. 131-150. Kieli 9. Helsinki: Helsingin yliopiston suomen kielen laitos.

Borg, SAMi 2012: Johdanto. - Sami Borg (toim.), Muutosvaalit 2011 s. 17-28. Helsinki: Oikeusministeriö.

Borriello, Arthur 2017: 'There is no alternative'. How Italian and Spanish leaders' discourse obscured the political nature of austerity. - Discourse \& Society 28 s. 241-261. https://doi.org/10.1177/0957926516687419.

BRINDle, ANDREW 2016: Cancer has nothing on Islam. A study of discourses by group elite and supporters of the English defence league. - Critical Discourse Studies 13 s. 444-459. https://doi.org/10.1080/17405904.2016.1169196.

Charteris-Black, Jonathan 2014: Analysing political speeches. Rhetoric, discourse and metaphor. Basingstoke: Palgrave Macmillan.

Chilton, Paul 2004: Analysing political discourse. Theory and practice. London: Routledge.

Dijk, Teun A. VAn 1992: Discourse and the denial of racism. - Discourse \& Society 3 s. 87-118.

_ 1993: Principles of critical discourse analysis. - Discourse \& Society 4 s. 249-283.

1997a: Political discourse and racism. Describing others in Western parliaments. - Stephen Harold Riggins (toim.), The language and politics of exclusion. Others in discourse s. 31-64. 
Thousand Oaks: Sage.

- 1997b: What is political discourse analysis? - Jan Blommaert \& Chris Bulcaen (toim.), Political linguistics s. 11-52. Amsterdam: John Benjamins Publishing Company.

2000: New(s) racism. A discourse analytical approach. - Simon Cottle (toim.), Ethnic minorities and the media s. 33-49. Maidenhead: Open University Press.

2016: Racism in the press. - Nancy Bonvillain (toim.), The Routledge handbook of linguistic anthropology s. 384-392. New York: Routledge.

Doerr, Nicole 2017: Bridging language barriers, bonding against immigrants. A visual case study of transnational network publics created by far-right activists in Europe

- Discourse \& Society 28 s. 3-23. https://doi.org/10.1177/0957926516676689.

Fairclough, Norman 1992: Discourse and social change. Cambridge: Polity Press.

- 1997: Miten media puhuu. Suomentaneet Virpi Blom \& Kaarina Hazard. Tampere: Vastapaino.

- 2001a: Critical discourse analysis as a method in social scientific research. - Ruth Wodak \& Michael Meyer (toim.), Methods of critical discourse analysis s. 121-138. London: Sage.

2001b: Language and power. New York: Longman

2003: Analysing discourse. Textual analysis for social research. London: Routledge.

Fairclough, Norman - Wodak, Ruth 1997: Critical discourse analysis. - Teun A. van Dijk (toim.), Discourse as social interaction s. 258-284. London: Sage.

Fonseca, Pedro - Ferreira, Maria João 2015: Through 'seas never before sailed'. Portuguese government discursive legitimation strategies in a context of financial crisis. - Discourse \& Society 26 s. 682-711. https://doi.org/10.1177/0957926515592780.

Gee, James Paul 2011: An introduction to discourse analysis. Theory and method. New York: Routledge.

Gramsci, Antonio 1988: Prison letters. A selection. London: Zwan Publications.

Gusterson, Hugh 2017: From Brexit to Trump. Anthropology and the rise of nationalist populism - American Ethnologist 44 s. 209-214. https://doi.org/10.1111/amet.12469.

HaAra, Paula 2012: Poliittinen maahanmuuttokeskustelu Helsingin Sanomien verkkokeskusteluissa. - Mari Maasilta (toim.), Maahanmuutto, media ja eduskuntavaalit s. 52-86. Tampere: Tampere University Press.

Haavisto, Camilla 2011: Conditionally one of 'us'. A study of print media, minorities and positioning practices. Helsinki: University of Helsinki.

Halliday, M. A. K. 1994: An introduction to functional grammar. London: Arnold.

Hatakka, Niko - Niemi, Mari K. - VÄlimäKi, Matti 2017: Confrontational yet submissive. Calculated ambivalence and populist parties' strategies of responding to racism accusations in the media - Discourse \& Society 28 s. 262-280. https://doi. org/10.1177/0957926516687406.

HeIKKINEN, VESA 1999: Ideologinen merkitys. Kriittisen tekstintutkimuksen teoriassa ja käytännössä. Helsinki: Suomalaisen Kirjallisuuden Seura.

Herneaho, Irina 2016: Maahanmuuttodiskurssit eduskuntapuolueiden vuoden 2015 vaalimateriaaleissa. Suomen kielen pro gradu -tutkielma. Jyväskylän yliopisto.

Hopgood, StePHen 2013: The endtimes of human rights. Ithaca: Cornell University Press.

Horsti, KARINA 2005: Vierauden rajat. Monikulttuurisuus ja turvapaikanhakijat journalismissa. Tampere: Tampere University Press.

Horsti, Karina - Nikunen, KaARINA 2013: The ethics of hospitality in changing journalism. A response to the rise of the anti-immigrant movement in Finnish media publicity. European journal of cultural studies 16 s. 489-504. https://doi.org/10.1177/1367549413491718. 
Johnstone, Barbara 2008: Discourse analysis. Malden: Blackwell.

Jokinen, Arja - Juhila, Kirsi - Suoninen, Eero 2012: Kategoriat, kulttuuri \& moraali. Tampere: Vastapaino.

Kajaste, Jussi 1995a: Luvat, mahdollisuudet ja velvoitteet. Suomen kielen pro gradu -tutkielma. Helsingin yliopisto.

_ 1995b: Poliittisen ohjelman retoriikasta ja argumentaatiosta. - Jyrki Kalliokoski (toim.), Teksti ja ideologia. Kirjoituksia kielestä ja vallasta julkisessa kielenkäytössä s. 184-204.

Kieli 9. Helsinki: Helsingin yliopiston suomen kielen laitos.

KAlliokoski, Jyrki (toim.) 1995: Teksti ja ideologia. Kirjoituksia kielestä ja vallasta julkisessa kielenkäytössä. Kieli 9. Helsinki: Helsingin yliopiston suomen kielen laitos.

KAlliokoski, JyRKi 1995a: Johdanto. - Jyrki Kalliokoski (toim.), Teksti ja ideologia. Kirjoituksia kielestä ja vallasta julkisessa kielenkäytössä s. 8-36. Kieli 9. Helsinki: Helsingin yliopiston suomen kielen laitos.

— 1995b: Kieli, tunteet ja ideologia uutistekstissä. Näkymiä tekstilajin historiaan ja nykyisyyteen. - Jyrki Kalliokoski (toim.), Teksti ja ideologia. Kirjoituksia kielestä ja vallasta julkisessa kielenkäytössä s. 37-97. Kieli 9. Helsinki: Helsingin yliopiston suomen kielen laitos.

Karjalainen, Anne-Maria - Luodonpä̈̈-Manni, Milla - Laippala, Veronika 2017: Hyvinvointivaltio ja kielitietoisuus. Hyvinvoinnin diskurssit neljän suurimman puolueen eduskuntavaaliohjelmissa. - Sirkku Latomaa, Emilia Luukka \& Niina Lilja (toim.), Kielitietoisuus eriarvoistuvassa yhteiskunnassa. AFinLAn vuosikirja 2017 s. 114-132. Jyväskylä: Suomen soveltavan kielitieteen yhdistys AFinLA.

Karlsson, Fred - Wiberg, Matti 2010a: Puolueilla on eroja! Periaateohjelma-analyysi. Politiikka 52 s. 54-66.

2010b: Puolueohjelmien kieliopillinen kompleksisuus. - Sananjalka 52 s. 89-103.

Karvonen, Pirjo 1995: Missä on taloustekstin ihminen? - Jyrki Kalliokoski (toim.), Teksti ja ideologia. Kirjoituksia kielestä ja vallasta julkisessa kielenkäytössä s. 151-167. Kieli 9. Helsinki: Helsingin yliopiston suomen kielen laitos.

Keskinen, Suvi 2009: Pelkkiä ongelmia? Maahanmuutto poliittisen keskustelun kohteena. - Suvi Keskinen, Anna Rastas \& Salla Tuori (toim.), En ole rasisti, mutta... Maahanmuutosta, monikulttuurisuudesta ja kritiikistä s. 33-45. Tampere: Vastapaino.

Keskinen, Suvi - Rastas, Anna - Tuori, SAlla (toim.) 2009: En ole rasisti, mutta... Maahanmuutosta, monikulttuurisuudesta ja kritiikistä. Tampere: Vastapaino.

KIRKWOOD, STEVE 2017: The humanisation of refugees. A discourse analysis of UK parliamentary debates on the European refugee 'crisis'. - Journal of community \& applied social psychology 27 s. 115-125. http://dx.doi.org/10.1002/casp.2298.

Koistinen, Niına 2010: Toimijaroolit ja roolien välinen dynamiikka Vihreän liiton periaateohjelmassa 2006. Suomen kielen pro gradu -tutkielma. Helsingin yliopisto.

KrZYŻANOWSKI, MiChAL 2013: From anti-immigration and nationalist revisionism to Islamophobia. Continuities and shifts in recent discourses and patterns of political communication of the Freedom Party of Austria (FPÖ). - Ruth Wodak, Majid KhosraviNik \& Brigitte Mral (toim.), Right-wing populism in Europe. Politics and discourse s. 135-148. London: Bloomsbury.

KS = Kielitoimiston sanakirja 2017. Helsinki: Kotimaisten kielten keskus. URN:NBN:fi:kotus201433. Verkkojulkaisu. Päivitetty 28.2.2017 (15.5.2017).

KUUSISTO, PЕКKA 2000: Ethnicity in print. Implicit linguistic manifestations of the construction of ethnicity in British and Finnish newspapers. Helsinki: University of Helsinki.

Lанті, Еммі 2014: Viherfemakot hyysäävät turvapaikkaturisteja ja pikkuhitlerit kitisevät. 
Ryhmien nimeämisestä, rakentamisesta ja toiminnasta maahanmuuttoaiheisissa verkkokeskusteluissa. Suomen kielen pro gradu -tutkielma. Helsingin yliopisto.

Lepola, Out i 2000: Ulkomaalaisesta suomenmaalaiseksi. Monikulttuurisuus, kansalaisuus ja suomalaisuus 199o-luvun maahanmuuttopoliittisessa keskustelussa. Helsinki: Suomalaisen Kirjallisuuden Seura.

Lu ukka, Minna-Riıt ta 200o: Näkökulma luo kohteen. Diskurssintutkimuksen taustaoletukset. - Kari Sajavaara \& Arja Piirainen-Marsh (toim.), Kieli, diskurssi \& yhteisö s. 133-16o. Jyväskylä: Solki.

MaAsilta, MARi (toim.) 2012: Maahanmuutto, media ja eduskuntavaalit. Tampere: Tampere University Press.

Martínez Guillem, Susana 2017: Race/ethnicity. - John Flowerdew \& John E. Richardson (toim.), The Routledge handbook of critical discourse studies s. 470-486. New York: Routledge.

Mickelsson, Rauli 2002: Sosialidemokraattien kertomukset. SDP:n periaateohjelmakeskustelu 1995-1999 kertomusanalyysin valossa. - Politiikka 44 s. 31-47.

- 2004: Vihreä liitto Suomen puoluekarttapallolla periaateohjelmien näkökulmasta tarkasteltuna. - Politiikka 46 s. 65-79.

Nikunen, KaARina 2010: Rakastamisen vaikeudesta. Internet, maahanmuuttokeskustelu ja tunteet. - Media \& viestintä 33 s. 7-26. https://doi.org/10.23983/mv.62919.

Niskanen, PaAvo 2011: Kokoomus sekä SDP porvariston ja työväestön asialla. - Politiikka 53 S. $123-135$.

Pietikäinen, Sari 20ooa: Kriittinen diskurssintutkimus. - Kari Sajavaara \& Arja PiirainenMarsh (toim.), Kieli, diskurssi \& yhteisö s. 191-217. Jyväskylä: Solki.

20oob: Discourses of differentiation. Ethnic representations in newspaper texts. Jyväskylä: University of Jyväskylä.

Pietikäinen, SARi - Mäntynen, Anne 2009: Kurssi kohti diskurssia. Tampere: Vastapaino.

Pohjolainen, Terese 2012: Vihreällä on viisi miljoonaa sävyä. Vihreyden retoriikka Kansallisen Kokoomuksen ympäristöpoliittisessa ohjelmassa 2011. Suomen kielen pro gradu -tutkielma. Jyväskylän yliopisto.

Pu uronen, Vesa 2011: Rasistinen Suomi. Helsinki: Gaudeamus.

РүчккӧNEN, MiıккA 2011: "Luonnollinen suomalaisuus" ja etnosentrismi kahdeksan suurimman puolueen eduskuntavaaliohjelmissa 2011. - Politiikka 53 s. 147-152.

PÄLli, PekKa 2003: Ihmisryhmä diskurssissa ja diskurssina. Tampere: Tampereen yliopisto.

PÖy HTÄRI, ReETA 2014: Immigration and ethnic diversity in Finnish and Dutch magazines. Articulations of subject positions and symbolic communities. Tampereen yliopisto: Tampere University Press.

Railo, ErkкA 2013: Kurissa ja globalisaation nuhteessa? Kokoomuksen, SDP:n ja Perussuomalaisten vaaliohjelmien suhtautuminen kansainvälistymiseen. - Tiedepolitiikka 38 s. 41-50.

Railo, ErkKa - Ruohonen, Sini 2016: Vaalikampanjat ja julkisuuden agenda. - Kimmo Grönlund \& Hanna Wass (toim.), Poliittisen osallistumisen eriytyminen. Eduskuntavaalitutkimus 2015 s. 76-94. Helsinki: Oikeusministeriö.

Raittila, Pentti (toim.) 2002: Etnisyys ja rasismi journalismissa. Tampere: Tampere University Press.

Reisigl, Martin - Wodak, Ruth 2001: Discourse and discrimination. Rhetorics of racism and antisemitism. London: Routledge.

Richardson, John - Colombo, Monica 2014: Race and immigration in far- and 
extreme-right European political leaflets. - Christopher Hart \& Piotr Cap (toim.), Contemporary critical discourse studies s. 521-542. London: Bloomsbury.

Shore, Sus AnNA 2012a: Kieli, kielenkäyttö ja kielenkäytön lajit systeemis-funktionaalisessa teoriassa. - Vesa Heikkinen, Eero Voutilainen, Petri Lauerma, Ulla Tiililä \& Mikko Lounela (toim.), Genreanalyysi. Tekstilajitutkimuksen käsikirja s. 133-157. Helsinki: Gaudeamus.

_ 2012b: Systeemis-funktionaalinen teoria tekstien tutkimisessa. - Vesa Heikkinen, Eero Voutilainen, Petri Lauerma, Ulla Tiililä \& Mikko Lounela (toim.), Genreanalyysi. Tekstilajitutkimuksen käsikirja s. 158-185. Helsinki: Gaudeamus.

Shore, Susanna - Mäntynen, Anne 2006: Johdanto. - Anne Mäntynen, Susanna Shore \& Anna Solin (toim.), Genre - tekstilaji s. 9-41. Helsinki: Suomalaisen Kirjallisuuden Seura.

Sisäministeriö 2014a: Väkivaltainen ekstremismi Suomessa - tilannekatsaus 2/2014. http://intermin.fi/documents/1410869/3723676/Vakivaltainen-ekstremismi-Suomessa-tilannekatsaus-2-2014.pdf/4548b2a9-64fo-4b24-bfo3-dd66b9ca6a1b (15-3.2018).

— 2014b: Sisäministeriö käynnistää uusia toimenpiteitä terrorismin uhan vähentämiseksi konfliktialueelle matkustaneiden osalta. http://intermin.fi/artikkeli/-/asset_publisher/ sisaministerio-kaynnistaa-uusia-toimenpiteita-terrorismin-uhan-vahentamiseksi-konfliktialueelle-matkustaneiden-osalta (15.3.2018).

Solin, AnNA 2002: Arvot vai ohjearvot? Ympäristönsuojelun merkityksistä hallinnon teksteissä. - Vesa Heikkinen (toim.), Virkapukuinen kieli s. 157-171. Helsinki: Suomalaisen Kirjallisuuden Seura.

Swales, John 1990: Genre analysis. Cambridge: Cambridge University Press.

Tervonen, Mirka 2014: Historiankirjoitus ja myytti yhden kulttuurin Suomesta. - Pirjo Markkola, Hanna Snellman \& Ann-Catrin Östman (toim.), Kotiseutu ja kansakunta. Miten suomalaista historiaa on rakennettu s. 137-162. Helsinki: Suomalaisen Kirjallisuuden Seura.

VisK = Hakulinen, Auli - Vilikuna, Maria - Korhonen, Rittta - Koivisto, Vesa - Heinonen, Tarja Rittta - Alho, Irja 2004: Iso suomen kielioppi. Helsinki: Suomalaisen Kirjallisuuden Seura. Verkkoversio. http://scripta.kotus.fi/visk (19.5.2017).

WoDAK, RUth 1991: Turning the tables. Antisemitic discourse in post-war Austria. - Discourse \& Society 2 s. 65-83.

_ 1993: 'We are dealing with people whose origins one can clearly tell just by looking. Critical discourse analysis and the study of neo-racism in contemporary Austria. - Discourse \& Society 4 s. 225-248.

2014: The strategy of discursive provocation. A discourse-historical analysis of the FPÖ's discriminatory rhetoric. - Matthew Feldman \& Paul Jackson (toim.), Doublespeak. The rhetoric of the far-rights since 1945 s. 101-122. Stuttgart: Ibidem-Verlag.

2015a: The Politics of fear. What right-wing populist discourses mean. London: Sage.

2015b: Discrimination via discourse. - Nancy Bonvillain (toim.), The Routledge handbook of linguistic anthropology s. 366-383. New York: Routledge.

2017: The "establishment", the "élites", and the "people". Who's who? - Journal of Language and Politics 16 s. 551-565. https://doi.org/10.1075/jlp.17030.wod.

Wodak, Ruth - Dijk, Teun A. van (toim.) 2000: Racism at the top. Parliamentary discourses on ethnic issues in six European states. Klagenfurt: Drava.

Wodak, Ruth - KhosraviNik, Majid - Mral, Brigitte (toim.) 2013: Right-wing populism in Europe. Politics and discourse. London: Bloomsbury.

Wodak, Ruth - Richardson, John E. (toim.) 2013: Analysing fascist discourse. European fascism in talk and text. New York: Routledge. 


\section{Discourses of immigration in parliamentary parties' political platforms 2015}

The article examines the ways in which Finnish parliamentary parties represent immigration in their political manifestos. Applying critical discourse analysis, the study discusses how inequality and power relations regarding immigration are legitimated, reproduced and challenged through discourse. The data employed was published during the campaign for the parliamentary election of 2015 and includes the sections of party manifestos which cover immigration, as well as the immigration policy paper by the Finns Party. The questions explored are what kinds of discourses of immigration the data portrays and how these discourses are constructed linguistically.

As a result, four different discourses of immigration have been identified. These include the discourses of economy, human rights, security and nationalism. Based on the analysis, the discourse of human rights can be interpreted as the main discursive tool used to challenge the status quo. In this discourse, immigration is justified by appealing to equality and international human rights commitments.

The discourse of economy is drawn upon by all parliamentary parties, construing it as a hegemonic way of representing immigration in the data. Economic discourse contains two different standpoints. The first perspective deals mainly with occupational immigration, in which case immigrants are welcomed, provided that they benefit the state economy either as workforce or as students. The other perspective represents immigrants, refugees and asylum seekers in particular, as an economic burden, thus reinforcing dominant power relations.

Constructing immigration as a threat is characteristic of the discourses of security and nationalism. The former concerns concrete security threats, such as crime and terrorism, whereas the latter presents immigration as an unnatural phenomenon that needs to be controlled in order to protect Finnish society and values. Both discourses are used as tools to legitimate the tightening of migration policies. 


\section{Maahanmuuttodiskurssit eduskuntapuolueiden vuoden 2015 vaalimateriaaleissa}

Artikkeli tarkastelee, millaisin kielellisin keinoin maahanmuuttoa kuvataan kevään 2015 eduskuntavaalimateriaaleissa. Tutkimus pohjautuu kriittisen diskurssintutkimuksen viitekehykseen, jossa kiinnostus kohdistuu erityisesti diskurssin rooliin eriarvoisuuden ja dominoivien valtasuhteiden tuottamisessa ja haastamisessa. Aineisto koostuu eduskuntapuolueiden vuoden 2015 vaaliohjelmien maahanmuuttoa käsittelevistä osista sekä perussuomalaisten maahanmuuttopoliittisesta ohjelmasta. Artikkelissa analysoidaan, millaisia maahanmuuttoon liittyviä diskursseja aineistosta on tulkittavissa ja millaisin kielellisin keinoin diskursseja rakennetaan.

Analyysin perusteella aineistosta on tulkittavissa neljä eri maahanmuuttodiskurssia, jotka ovat yleisyysjärjestyksessä talous-, ihmisoikeus- ja turvallisuusdiskurssi sekä nationalistinen diskurssi. Näistä hierarkkisia valtasuhteita vastustamaan asettuu ihmisoikeusdiskurssi, jossa maahanmuuttoa tarkastellaan sekä maahanmuuttajien oikeuksien että Suomen velvollisuuksien näkökulmasta. Talousdiskurssi puolestaan edustaa hegemonista merkityksellistämisen tapaa, sillä jokainen puolue käsittelee maahanmuuttoa taloudellisena kysymyksenä. Diskurssin sisällä on kuitenkin variaatiota siinä, esitetäänkö maahanmuutto kansantalouden kannalta hyödyllisenä vai haitallisena ilmiönä. Taloudellisilla argumenteilla perustellaan sekä maahanmuuton helpottamista että sen rajoittamista.

Maahanmuutosta luodaan uhkaavaa kuvaa myös turvallisuusdiskurssissa sekä nationalistisessa diskurssissa, joista molempia käytetään legitimoimaan tiukempaa maahanmuuttopolitiikkaa. Turvallisuusdiskurssissa konstruoidut uhat ovat konkreettisia, kuten rikollisuutta ja terrorismia. Nationalistisessa diskurssissa kyse on symbolisesta uhasta, jonka esitetään juontuvan maahanmuuttajien oletetusta erilaisuudesta ja sopeutumattomuudesta suomalaiseen yhteiskuntaan.

Kirjoittajan yhteystiedot (address):

etunimi.sukunimi@helsinki.fi

Kirjoittaja on suomen kielen väitöskirjatutkija Helsingin yliopistossa. 